\title{
EXTERNAL IMBALANCES AND RECOVERIES
}

\section{0}

\section{BANCODEESPAÑA}

Eurosistema

Documentos de Trabajo

N. ${ }^{\circ} 2012$

Mariam Camarero, María Dolores Gadea-Rivas, Ana Gómez-Loscos and Cecilio Tamarit 
EXTERNAL IMBALANCES AND RECOVERIES ${ }^{(*)}$

\section{Mariam Camarero}

UNIVERSITY JAUME I AND INTECO

\section{María Dolores Gadea-Rivas}

UNIVERSITY OF ZARAGOZA

\section{Ana Gómez-Loscos}

BANCO DE ESPAÑA

\section{Cecilio Tamarit ${ }^{(* *)}$}

UNIVERSITY OF VALENCIA AND INTECO

$\left.{ }^{(*}\right)$ The authors are grateful to the participants at the Joint Conference CFE-CMStatistics London-2017, the 5th International Symposium in Computational Economics and Finance (ISCEF-Paris) for their input, as well as to Elisa Wu for her detailed discussion provided at the Infiniti Conference, Poznan-2018. We also acknowledge the financial support from the Agencia Estatal de Investigación-FEDER ECO2017-83255-C3-2-P, ECO2017-83255-C3-3-P projects and PROMETEO/2018/102.

$\left.{ }^{\star *}\right)$ Corresponding author: Avda. Tarongers.46071 Valencia. email: cecilio.tamarit@uv.es. 
The Working Paper Series seeks to disseminate original research in economics and finance. All papers have been anonymously refereed. By publishing these papers, the Banco de España aims to contribute to economic analysis and, in particular, to knowledge of the Spanish economy and its international environment.

The opinions and analyses in the Working Paper Series are the responsibility of the authors and, therefore, do not necessarily coincide with those of the Banco de España or the Eurosystem.

The Banco de España disseminates its main reports and most of its publications via the Internet at the following website: http://www.bde.es.

Reproduction for educational and non-commercial purposes is permitted provided that the source is acknowledged.

(C) BANCO DE ESPAÑA, Madrid, 2020

ISSN: 1579-8666 (on line) 


\section{Abstract}

A decade after the beginning of the Great Recession, flow external imbalances, measured by the current account (CA) have narrowed markedly. However, stock or net foreign assets (NFA) imbalances have kept increasing and have created challenges for future macroeconomic and financial stability. To date, early warning systems (scoreboards) have focused more on flow than on the stock variables. To approach this problem, in this paper we analyze expansions using two complementary sets of indicators proposed by Harding and Pagan (2002) and Gadea et al. (2017). After controlling for a large set of explanatory variables, we find that the effect of CA imbalances is limited, except when the measures selected take into account past CA developments or some degree of persistence. In contrast, the evolution of NFA seems to be much more explanatory of the time it takes to regain the level of output previous to the recession, as well as the amplitude and the cumulation of the recoveries. Therefore, we conclude that future macro-prudential policies should pay more attention to stock variables to measure external imbalances due to their effects on the characteristics of recoveries.

Keywords: business cycles, recoveries, NFA, external imbalances, current account.

JEL classification: F21, R12, C23. 


\section{Resumen}

Una década después del comienzo de la Gran Recesión, los desequilibrios externos, medidos por la cuenta corriente [current Account (CA)], se han reducido notablemente. Sin embargo, los desequilibrios externos medidos a través de variables de stock, es decir, la posición de inversión internacional [net Foreign Assets (NFA)], han seguido aumentando y han creado desafíos para la estabilidad macroeconómica y financiera. Hasta la fecha, los sistemas de alerta temprana se han centrado más en las variables de flujo que en las variables de stock. En este documento se analizan los efectos de ambos desequilibrios sobre las características de las expansiones, utilizando dos conjuntos complementarios de medidas, propuestas por Harding y Pagan (2002) y Gadea et al. (2017). Tras controlar por un conjunto amplio de variables explicativas, se identifica que el efecto de los desequilibrios de la CA sobre las expansiones es limitado, excepto cuando las medidas seleccionadas tienen en cuenta los desarrollos pasados de la CA o algún grado de persistencia. En cambio, la evolución de la NFA parece explicar mejor el tiempo que se tarda en recuperar el nivel de PIB anterior a la recesión, así como la amplitud y la acumulación de las recuperaciones. Estos resultados apuntarían a que las futuras políticas macroprudenciales deberían prestar más atención a las variables de stock para medir los desequilibrios externos, debido a sus efectos sobre las características de las recuperaciones.

Palabras clave: ciclos económicos, recuperaciones, posición de inversión internacional, desequilibrios externos, cuenta corriente.

Códigos JEL: F21, R12, C23. 


\section{Introduction and motivation}

The increasing and persistent external imbalances experienced in the world economy since the nineties have led to a revival on the old debate of the costs and benefits of economic integration and globalization for growth. Moreover, in the aftermath of the Great Recession (GR hereafter), some countries are facing difficulties to recover the level of output they reached prior to the start of the recession. The speed of recovery seems to be different among OECD countries and, in particular, between core and peripheral countries in the euro area (EA). This paper aims at connecting both elements, that is, considering the effects of external imbalances as one of the main drivers of the speed and shape of recoveries, has clear economic policy implications, in particular in the design of appropriate macroprudential policies.

After years of large and global external imbalances, their actual prospective developments and their impact on future growth remain a matter for concern. Prior to the GR, the very loose external financing conditions led to asset bubbles and credit booms in a number of countries, widening global imbalances. This fact was perceived as one of the main risks to the global economy. Then, the GR gave rise to a sudden-stop, tightening the financing conditions and leading to a reassessment of external credit risk.

Some international institutions (IMF (2014) $)^{1}$ and practitioners ${ }^{2}$ alike have emphasized the external adjustment following the GR in flow and stock terms. Global imbalances have been traditionally characterized as divergences in the current account flows leading to a divide between surplus (i.e. BRICs, oil exporters, Japan and some EU core economies) and deficit countries (mainly, the United States and some peripheral EU countries). Catão and Milesi-Ferretti (2014) calculate the difference between the actual and a fitted current account value for the period 2005-08 that they call the "CA gap" and relate the subsequent change in the CA balance (2012 minus average 2005-08) to the CA gap and the NFA positions, respectively. They also check for differences between countries in fixed exchange rate regimes and other exchange rate arrangements. They find that global current account ("flow") imbalances have narrowed significantly since their peak in 2006. However, these reductions in global flow imbalances have been contemporaneous with increasing stock imbalances. Indeed, since flow imbalances have diminished but not reversed, net creditor and debtor positions, that is, "stock imbalances", have widened further over time. Moreover, they find that adjustments reflect primarily compression of demand and output in countries with excess deficits, and swings in net debt flows, the real exchange rate adjustment playing just a modest role and being limited to pegged systems. Although the reduction of

\footnotetext{
${ }^{1}$ From early 2004, the International Monetary and Financial Committee (IMFC) of the IMF had set out in each of its communiqués the policies needed to help facilitate an orderly adjustment of global imbalances. Since 2012, the IMF has again stepped up its work on imbalances with the External Sector Report (ESR) that has been published annually since then, drawing on estimates from the External Balance Assessment (EBA) approach as well as country-specific evidence.

${ }^{2}$ Catão and Milesi-Ferretti (2014).
} 
large flow imbalances has diminished systemic risks to the global economy, the nature of the flow adjustment, mostly driven by persistent expenditure compression in deficit countries, led to a slow rebalancing process that has threatened the shape and dynamics of the recovery in the business cycle. In 2017, the IMF integrated its global imbalances analysis into a new pilot Report on Strong, Sustainable and Balanced Growth (IMF (2018a)) which takes a holistic view of the achievements of G20 economies linking global imbalances with growth patterns among other factors. Moreover, the IMF in its latest periodical assessment of the External Sector Report (ESR) ${ }^{3}$, warns about the risks of persistent excess imbalances and their concentration in developed economies. In fact, the refined External Balance Assessment Methodology (EBA) developed by the IMF in that report points to the external imbalances as the major threat for trade tensions and global stability in the medium term.

This problem is especially relevant for establishing the correct exit strategies in the case of the EA and to achieve an accurate design of prudential policies within the new governance of the $\mathrm{EU}^{4}$. Large current account deficits in the South and East of the EU were not sustainable and hence these countries faced major balance of payments crises after 2008 (Darvas (2012)). The current accounts of these countries moved to either a balanced position or even surplus, boosted by trade balance improvements. However, because of the accumulated large stock of foreign liabilities, it might take many years of large current account surpluses in Southern and Eastern EU countries to significantly reduce these liabilities.

Therefore, there is currently a debate among policy makers in international institutions (IMF, European Commission, OECD, etc.), governments and central banks ${ }^{5}$ about the longterm scenarios after the GR and the exit strategies. Now a rapid V-shape exit has been discarded and a double-dip (W-shape) has been witnessed in some countries (i.e. some EA countries), the debate is focusing on possible $U$ or L-shape exit paths as a result of the deleveraging process, possibly due to a debt overhang, the so-called "debt legacy". According to European Commission (2018a) the depth of the downturn was linked to the limited absorption capacity of EA members, but also to the fact that the crisis coincided with the unwinding of accumulated current account imbalances.

After the financial crisis it has become evident that not only emerging but also developed countries have increased their external vulnerability due to the process of financial globalization, in general, and the creation of a monetary union in Europe, in particular. ${ }^{6}$ For this reason, this study extends the analysis of the impact of the net external position on recoveries to both developed and developing nations. We use a large sample of OECD

\footnotetext{
${ }^{3} \mathrm{IMF}(2018 b)$.

${ }^{4}$ Among EU countries, large and persistent current account deficits before the 2008 global financial crisis resulted in the accumulation by several Southern and Central European countries of large stocks of net foreign liabilities, while many Western and Northern European countries accumulated net foreign assets because of their current account surpluses.

${ }^{5}$ See, among others, European Commission (2018a), European Commission (2018b) and IMF (2018b).

${ }^{6}$ De Grauwe (2012b) coined the term fragility for the Eurozone.
} 
countries from 1950 up to the present. The source for GDP is the Quarterly National Accounts elaborated by the OECD. The current account balance as a percentage of GDP (CA henceforth) has been extracted from the OECD and Eurostat. Finally, the net foreign assets to GDP ratio (NFA henceforth) are obtained from the updated Lane and Milesi-Ferretti (2001) database, covering the period 1983 - 2014. NFA is used as an alternative measure of the net external position ${ }^{7}$ and is obtained as the value of assets owned by domestic residents held abroad minus the value of domestic liabilities to the rest of the world. A country, therefore, can be either a net creditor $(N F A>0)$ or a net debtor $(N F A<0)$. In the $E M U$, the relative external positions of its members have been deeply asymmetrical: whereas some countries have large current account surpluses (principally Germany, but also the Netherlands and Denmark), the majority of the peripheral countries have experienced sizable deficits reaching 10 per cent or more in the first decade of this century.

The purpose of this paper is twofold. First, we assess the role that external imbalances may have on the characteristics of expansions, including their duration and depth, as well as on the speed and shape of the recovery ${ }^{8}$. Second, we compare different metrics of flow and stock definitions of the imbalances and determine whether stocks or flows may have more explanatory power as drivers of recovery patterns as well as of the duration of the expansions and other characteristics of the cycle, such as the time to recover the GDP to its level before the crisis.

From an economic policy point of view, the governance of the European Union and, in particular, the EA, has been reformed after the GR. The Macroeconomic Imbalance Procedure (MIP hereafter) was approved in 2011 to provide a warning mechanism that establishes a surveillance and prevention procedure to identify and correct the imbalances. This mechanism is based on a scoreboard of indicators used as thresholds to identify those countries which need a closer analysis. Some of these indicators some of them are related to the external position of the countries: the current account balance, the net foreign assets position, the real effective exchange rate and the export market share. Our hypothesis is that indicators of the stock external imbalances can be more explanatory of recoveries than flow indicators and, accordingly, future macroprudential policies should pay more attention in stock variables, such as the NFA position.

The remainder of the paper is organized as follows: in section 2 we provide a very brief review of the relevant theoretical and empirical literature, as well as the formulation of the tested hypotheses; Section 3 describes our methodology and highlights the key difficulties caused by measurement problems. It also introduces the econometric specification of the models and a description of the data, while the main empirical results are discussed in Section 4 . Finally, Section 5 sets out the conclusions.

\footnotetext{
${ }^{7}$ The choice of this variable for the analysis is widely discussed in Section 4 .

${ }^{8}$ We distinguish between expansions and recoveries. Expansion is the cyclical phase that goes from the through to the peak, while by recovery, we refer to the first stages of an expansion.
} 


\section{Theoretical and empirical background}

The GR revealed that both global governance at the G20 level (based on the so-called Washington consensus) and the one for EMU were ill designed. They were too confident in market discipline to avoid excessive macroeconomic imbalances. In the real world, agents show persistence and inertia; for those countries that suffered large imbalances in the eve of the crisis, the question is whether this can be a constraint for recovery and long-run growth prospects. The crisis highlighted the need to strengthen economic resilience in EMU, defined as the ability of a country to avoid or withstand a shock and for GDP growth to recover quickly to its potential level after recession. Blanchard (2015) has emphasized that after the crisis, output growth may have slowed down, calling for the concepts of hysteresis or super-hysteresis initially coined by Ball (2014). The rationale behind this reasoning is that high levels of external leverage may divert resources from investment and other productive uses to service the debt, reducing growth in the long-run and leading to a Secular Stagnation process. The theoretical literature has distinguished between the positive shortrun effects of accumulating external imbalances to finance investment, and the negative long-run growth effects of high levels of indebtedness. The supporting empirical evidence, however, mainly focuses on developing countries, leading to a wide variety of results. ${ }^{9}$

The GR has shown the need for a new theoretical paradigm. The fact that output gap and output growth are non-normally distributed, exhibiting excess kurtosis and fat tails, is an important property of the dynamics of the business cycle, as shown by Fagiolo et al. (2008). According to De Grauwe (2012a) this implies that business cycle movements are characterized by periods of relatively small changes in output interrupted by (infrequent) periods of large change. Mainstream macroeconomic models explain the business cycle by invoking exogenous shocks that are non-normally distributed. However, a satisfactory macroeconomic theory should try to explain the occurrence of non-normality in the movements in output from within the theory. In fact, a large literature has emerged attempting to introduce imperfect information into macroeconomic models based mainly on the statistical learning approach pioneered by Sargent (1993) and Evans and Honkapohja (2001). An alternative explanation to model agents' behavior under imperfect information can be posed by behavioral macroeconomic models. In this vein, De Grauwe (2012a) explains endogenous business cycles based on a behavioral macroeconomic model, in which agents are assumed to have limited cognitive abilities, generating waves of optimism and pessimism.

The ability of an economy to recover affects how persistent the effects of shocks to the economy are. It reflects the capacity to ensure a swift return to the previous status, when the shock is temporary, or a smooth reallocation of productive resources, which is affected by product and labour market flexibility where shocks are more permanent. Resilient economic structures can be defined as those which prevent economic shocks from having significant and persistent effects on income and employment levels, and thus are

\footnotetext{
${ }^{9}$ See, for a review of the literature, Pattillo et al. (2011).
} 
able to reduce the impact of economic fluctuations. This is particularly relevant in a monetary union, where the policy instruments to address the effects of significant economic events are more limited and where inflation differentials can exacerbate real interest rate differentials that may eventuallly magnify shocks by fuelling economic booms.

Although in the business cycle literature the role of the external position of countries is not in the center of the analysis, we argue that the evolution of external disequilibria play a crucial role in the speed of recoveries after a recession. In what follows we present a brief overview of the theoretical fundamentals which will help us to single out the main testing hypotheses as well as to understand the empirical results.

We will start by analyzing the more general external imbalances-growth nexus and then we will tocus on the possible impact of these disequilibria on the shape and speed of business cycle recoveries.

The fulfillment of the neoclassical theory would imply a negative relationship between growth and the net external position of a country: this means that creditor countries would reduce their growth rate whereas debtor countries will increase it thanks to the contribution of external resources. More recent theoretical developments, although they have qualified the timeline of these results, did not modify the main conclusions. Empirical evidence, however, does not always support the neoclassical theory and the macroeconomic effects in terms of external imbalances derived from the current increasing globalization. In particular, important stylized facts of the international capital markets are difficult to be reconciled with the predictions of the neoclassical theory. For example, the US has been importing capital since 1982, coming from emerging economies (Stylized Fact 1 in Gourinchas and Rey, 2014). In addition, productivity growth and net capital inflows are not always positively related, what is commonly known as the "allocation puzzle" (Gourinchas and Jeanne, 2013). Therefore, this literature has evolved, trying to find alternative theories to provide a better explanation of the nature of the external imbalances and their effects on growth across countries. Accordingly, the focus shifted from macroeconomic variables to microeconomic frictions in financial markets. If wealth plays a role as collateral when borrowing, autarky interest rates might be lower in capital-scarce countries than in capital-abundant ones due to the higher risk involved in financial transactions in capital-scarce countries, even if its marginal product of capital is higher. Financial market imperfections (even if the return to investment is potentially high) can reduce the autarky interest rate, limiting investment and driving saving abroad, as in the models of Caballero et al. (2008) and Mendoza et al. (2009). As Broner and Ventura (2016) show, contrary to the representative-agent benchmark models, where financial globalization always lead to capital inflows in developing countries, the effects of financial globalization are heterogenous. If financial globalization occurs at high levels of development, we are under multiple equilibria: there will be capital imports and higher growth under optimist expectations and capital exports and lower growth under pessimism giving rise to recurrent cycles of high 
and low-growth periods. A seemingly successful economy might suddenly face a shift from optimism to pessimism under a self-fulfilling expectations process that results in a sudden stop in capital inflows, reversing into capital outflows and a reduction in investment and growth. More recently, Schmitt-Grohé and Uribe (2018) establish the existence of multiple equilibria in infinite-horizon open economy models in which the value of tradable and nontradable endowments serves as collateral. In this environment, the economy is shown to display self-fulfilling financial crises in which pessimistic views about the value of collateral induce agents to deleverage not only in case of overborrowing but also in the case of underborrowing.

Concerning the empirics, as pointed out by Checherita-Westphal and Rother (2012), the literature has focused until recently on the role of external debt in developing countries and found this to be a key predictor of financial crises in emerging economies. A recent strand of literature aims at ascertaining whether and to what extent the external debt-growth nexus depends on country-specific characteristics, such as the quality of their policies and institutions, obtaining heterogenous results across countries and time periods (Catão and Milesi-Ferretti (2014) and Camarero et al. (2018)).

A second strand of the empirical literature has focused on the relationship between external imbalances and the business cycle. A very relevant contribution on this specific issue was made by Jordà et al. (2011). Their main goal is to ascertain the relative role that credit and external imbalances play in the business cycle using a long span of data of 14 OECD countries that represent around 50\% of world GDP. They conclude that both the current account and credit have a significant predictive power as to the start of a recession. However, they do not assess the role of the two variables in the recoveries. Moreover, they measure the external imbalances using the flow variable (the current account) instead of the stock (net foreign asset position).

Turning our focus to the recoveries, many papers review the channels through which high external debt levels affect macroeconomic recoveries. High external debt levels hinder the ability of households and enterprises to smooth consumption and investment. In addition, the ability of governments to cushion adverse shocks can become impaired. Furthermore, large external debt levels can create vulnerabilities to shocks and can amplify and transmit macroeconomic and asset price shocks throughout the economy and internationally.

There are several mechanisms that can be pointed out. Bordo and Haubrich (2012) make a thorough revision of the literature on stylized facts concerning recoveries after a recession. ${ }^{10}$ Let us review the different elements in a deeper way.

\footnotetext{
${ }^{10}$ They point out that recessions associated with financial crises are generally followed by rapid recoveries. However, this has not been the case in three particular instances: the recovery from the 30s' Great Contraction, the recovery after the early 1990s recession and the present recovery. Trying to explain recoveries after financial crises they analyze 27 cycles for the American economy starting in 1882. They look at different potentially explanatory factors (such as bank lending and credit crunches) but attribute the sluggishness in the current recovery to the crisis of residential investment (their mesure of the housing market), that used to be a key predictor of recessions and recoveries.
} 
First, at higher debt levels exposure to asset price movements may become more of a problem for companies, governments -even though they can be indebted towards their own citizens- and households. ${ }^{11}$ Borrowers that use assets as collateral (e.g. stocks and housing) are limited in their ability to borrow, and hence to invest if the market value of collateral declines, which may induce deleveraging (Bernanke and Gertler (1990) and Kiyotaki and Moore (1997)). Second, for government, revenues can quickly lose their buoyancy when asset prices fall, as happened during the recent crisis ${ }^{12}$. Government budgets are affected by cyclical weakness as other sectors deleverage, through automatic budget reactions as well as counter-cyclical fiscal policy. ${ }^{13}$ Recent experience demonstrates that, at times, contagion from the private to the public sector can undermine government access to capital markets when "fiscal space" is limited, thereby forcing governments to become pro-cyclical during economic downturns.

Third, balance-sheet vulnerabilities can also lead to self-fulfilling runs or sudden stops when capital flows dry up, as shown by Mendoza and Smith (2006). When corporate and household balance sheets are impaired, the subsequent deleveraging can affect other sectors. Due to such repercussions, creditors can view private and public debt together when a crisis erupts (Díaz-Alejandro (1985)). Moreover, the transmission of financial crises and exposure to foreign currency denominated debt can increase risk and amplify macroeconomic volatility, as Korinek (2011) argued. Empirical work, such as Aizenman et al. (2013) suggests that financial openness exacerbates the effect of adverse financial shocks on real output. Such a pattern would be consistent with sudden stops à la Mendoza. Davis (2014) concentrates on the role of financial integration in the transmission of international shocks. He concludes that the results depend on the type of financial integration: credit, FDI or equity. International effects may be negative in the case of equity integration, when losses and gains are shared more or less equally (this is the traditional result from Real Business Cycle models, through the wealth effect) or positive if credit market integration prevails (balance sheet effects are asymmetric, as losses are shared -especially after default-, whereas in case of gains the debtor only pays interest rates).

Up to now, however, the empirical evidence is far from being conclusive and calls for further research. The literature so far has stressed the importance of financial (banking) crises vis-à-vis external imbalances to explain the frequency and depth of the recoveries. Jordà et al. (2011) show that banking sector pro-cyclicality can amplify cycles in the real economy and financial market instability can lead to severe downturns. Concerning other possible explanations of the different speeds of recovery, a whole strand of literature fo-

\footnotetext{
${ }^{11}$ Financial accelerator models show how shocks can be amplified, particularly when asset price boom-bust cycles act through the value of collateral, which accentuates cyclical fluctuations and may generate debtdeflation pressures during a downturn.

${ }^{12}$ This can squeeze government budgets, even if during an economic downturn interest rates are low. The deterioration in the budget may also undermine perceptions of sustainability.

${ }^{13}$ Sutherland and Hoeller (2012) suggest that run-ups in corporate borrowing in the previous five years (in both the financial and to a lesser extent the non-financial sector) tend to Granger cause increases in public sector debt.
} 
cuses on the role of housing investment and relatively loose monetary policy for some of the countries in EMU (Jordà et al. (2015)); in a previous work, and using the same data, Jordà (2014) studies the role of credit, the current account and private debt accumulation to predict recessions. The current account turns out not to be a good predictor, but helps sorting expansions from recessions. Claessens et al. (2012) reach similar conclusions concerning financial integration, but they also account for additional explanatory factors for the speed of recovery. Openness and financial sector development have significant and opposite signs: larger financial systems hamper the recovery. The current account also plays a role: countries with better positions tend to recover more strongly, as they are less vulnerable to adverse international developments (including limits to financing). Cerra et al. (2013) conclude that financial and macroeconomic shocks are more costly on emerging countries, whereas terms of trade and interest rate shocks are worse for developing economies. In both cases more open countries recover more slowly. More recently, Cerra and Saxena (2017) find that all types of recessions, on average, and not just those associated with financial and political crises as in Cerra and Saxena (2008), lead to permanent output losses. They conclude that persistent losses require more counter-cyclical and prudential policies. However, postulating that either credit imbalances or external imbalances have a role in business cycles' recoveries can be considered two sides of the same coin. Current account imbalances can, in fact, capture processes in the real economy that have to do with the functioning of the goods and services markets as well as the ability of the economy to finance itself.

Therefore, in what follows we will focus on the relationship between external imbalances and several expansion features, such as the speed of recoveries. The underlying hypothesis is that those countries with high external deficits recover more slowly as global shocks hit them severely. This can be particularly true for the case of the EA countries ${ }^{14}$.

Full assessment of external imbalances and its consequences for growth requires a comprehensive approach where dynamics should capture the feedback effects between the macroeconomic real sector and the financial one. However, there are just a few empirical studies that apply this approach ${ }^{15}$, and therefore, in general, they are unable to capture the stock-flow mechanism involved between the CA (flows) and the NFA (stock), an exception being Camarero et al. (2013). Thus, in addition to the contribution that the current account may have in the occurrence and depth of a crisis, we also claim that the accumulation of negative external imbalances compromises the ability to recover. The high degree of international financial integration may have exacerbated this tendency more recently.

In this paper, we stress this difference and compare the explanatory ability of both variables to interpret the depth and evolution of the recoveries.

\footnotetext{
${ }^{14}$ The underlying hypothesis is that the recent crisis has been, in origin, a balance of payments crisis that has caused a "sudden stop" in the Eurozone. This hypothesis is considered now a consensus view in Baldwin and Giavazzi (2015), although Mayer (2011) sustained it and shared it with Hans-Werner Sinn previously.

${ }^{15}$ See Glick and Rogoff (1995) and Milesi-Ferretti Assaf (1996).
} 
Therefore, the testing hypotheses to be analyzed in the present paper are the following:

$H_{1}$ : The depth and duration of the crises are larger in countries with external imbalances and debtor external positions. Also in this case recoveries are slower and it takes more time to return to the pre-crisis GDP level.

$H_{2}$ : The NFA position is a better predictor than the CA to capture these effects on the characteristics of recoveries and expansions.

\section{Measuring the effects of external imbalances on expansions}

The empirical approach used in this paper is based on the following steps. First, we obtain the business cycle chronology using the NBER methodology developed by Bry and Broschan (1971), which is applied to each individual country to obtain its business cycle dating. Second, we disentangle and characterize expansions using two complementary methods: (i) we compute the traditional measures of expansions of Harding and Pagan (2002) and (ii), we use the measures proposed by Gadea et al. (2017), which focus on the shape of expansions. Third, we measure the effect of external imbalances on expansions by running cross-country multiple regressions ${ }^{16}$ in which the endogenous variables are the traditional and the shape-related measures on expansions and the exogenous variables capture imbalances as functions of CA and NFA. Additionally, we include several control variables, such as trade openness, financial development, exchange rate regime or labour market regulations. Next, we detail the data used in our analysis.

\subsection{Data}

We use a wide sample of OECD countries from 1950 to the present. Specifically, it consists of 46 developed and developing countries. The source of GDP data is the Quarterly National Accounts elaborated by the OECD. ${ }^{17}$

Regarding the external position, the flow variable we use is the annual current account balance in percentage of GDP (CA/GDP), which has been extracted from OECD and Eurostat. Figure 1 displays the evolution of CA/GDP of the selected set of countries and compared with the business cycles dating of each of them. The stock variable to measure

\footnotetext{
${ }^{16}$ As one of the reviewers has pointed out, our database is cross-section and does not have a common time dimension. However, each country has several observations, that correspond to all the expansions that are obtained from the analysis.

${ }^{17}$ Specifically, the series is Gross Domestic Product, expenditure approach, volume estimates in millions of national currency, quarterly and seasonally adjusted. The countries and their codes are the following Argentina (ARG), Australia (AUS), Austria (AUT), Belgium (BEL), Brazil (BRA), Canada (CAN), Chile (CHL), Colombia (COL), Costa Rica (CRI), Cyprus (CYP), Czech Republic (CZE), Denmark (DNK), Estonia (EST), Finland (FIN), France (FRA), Germany (DEU), Greece (GRC), Hungary (HUN), Iceland (ISL), India (IND), Indonesia (IDN), Ireland (IRL), Israel (ISR), Italy (ITA), Japan (JPN), Korea (KOR), Latvia (LVA), Lithuania (LTU), Luxembourg (LUX), Malta (MLT), Mexico (MEX), Netherlands (NLD), New Zealand (NZL), Norway (NOR), Poland (POL), Portugal (PRT), Saudi Arabia (SAU), Slovak Republic (SVK), Slovenia (SVN), South Africa (SAF), Spain (ESP), Sweden (SWE), Switzerland (CHE), Turkey (TUR), the United Kingdom (GBR) and the United States (USA).
} 
the indebtedness of a country to foreigners is the net foreign asset position (the difference between foreign assets and foreign liabilities) relative to the size of the economy (GDP), which we denote NFA/GDP. These data are obtained from the updated Lane and MilesiFerretti (2001) database. Figure 2 shows the evolution of NFA/GDP of each country over the sample.

The links discussed above suggest that a high external debtor position can lead to vulnerabilities and undermine macroeconomic stability. An adverse shock can tip the economy into recession. Examining the relationship between debt and macroeconomic stability faces a number of problems. First, the lack of long time series and comparable data presents a serious obstacle. For instance, for most developing countries, data only exist for the last business cycle, which was characterized by the Great Recession. As such the analysis covers a period which is somewhat atypical. Second, accounting differences across countries complicate cross-country comparisons.

Additionally, regarding NFA, gross and net debt can differ across countries and sectors depending on what items are included in external debt. Another potential problem may arise if the face value of debt masks differences due to debt structure, such as the division between principal and coupon payments, Dias et al. (2014). Moreover, aggregate sectoral balance-sheet data may mask significant heterogeneity within a sector. For example, debt highly concentrated among households and firms that are least able to bear it may create vulnerabilities, even if the aggregate balance-sheets appear reasonably healthy. Many of the former drawbacks on the NFA variable can be circumvented using the EWN database, as we do in this paper. We obtain end-of-year series on foreign assets and liabilities from Lane and Milesi-Ferretti (2001, 2007), kindly updated by Gian Maria Milesi-Ferretti. Foreign (or external) assets are measured as the dollar value of assets a country owns abroad, while foreign (or external) liabilities refer to the dollar value of domestic assets owned by foreigners.

\subsection{Business cycle dating}

Burns and Mitchell (1946) proposed a method to describe the business cycle using a twostage methodology. First, turning points of different series are located by using graphical methods. Second, the specific cycle information is drawn out as a single set of turning points that identify the reference cycle. They also define concepts such as peak (the highest point of an expansion) and trough (the worst moment in a recession period) to determine the cycle length. Their aggregate cycle was called the business cycle, and their tools were immediately used by the National Bureau of Economic Research (NBER) to study US business cycles in greater depth. Nowadays, the NBER continues to publish a single set of turning points for the US economy, updating the series since 1854. However, such an official business cycle dating is not available for every country in our sample. 
Bry and Broschan (1971) (BB hereafter) developed the most popular non-parametric method to determine when the peaks and troughs, which frame economic recessions or expansions, appear. This algorithm works by looking for local minimums and maximums in a time series and has its own systems of smoothing and controlling the alternation of peaks and troughs. This method is robust against outliers and against changes in volatility, but it does not allow inferences or predictions to be made.

In the last few decades, many alternative procedures have been suggested. Among them, the Markov-switching (MS) approach proposed by Hamilton (1989) stands out. ${ }^{18}$ Unlike the BB method, the MS first fits a statistical model to the data and then uses the estimated parameters to determine the turning points of a series, being its main advantage the possibility to make inference. Nevertheless, this method has some problems when the sample size is small and it is very sensitive to changes in volatility.

To determine turning points, we use the non-parametric BB approach to date the business cycles of each country of our sample, ${ }^{19}$ that is, we identify each cyclical phase (expansions and recessions) of every country and then, focus on expansions. We have a database of expansions $\operatorname{Exp}_{i j}$, where $i=1, \ldots, N$ denotes the country and $j=1 \ldots n_{i}$ each of the expansions of country $i^{20}$ This makes a total of $M=\sum_{i=1}^{N} n_{i}$ expansions. Figures 1 and 2 display the chronology of the business cycles of the 46 countries in our sample together with the evolution of CA and NFA, respectively. ${ }^{21}$ Grey bars indicate recession periods. It can be observed that the number and date of expansions is quite heterogenous among countries. We identify a total of 259 expansions for the whole group of countries. ${ }^{22}$

\subsection{Dissecting expansions}

Once expansions of every country have been identified, we dissect and characterize expansions by computing two sets of measures: the traditional measures proposed by Harding and Pagan (2002) and the shape-related measures of Gadea et al. (2017).

Expansions go from a trough, that is, the lowest level of activity, to a peak, that is the highest point of activity. For easiness of interpretation, we assume that the trough (where the expansion begins) is located at the origin of the axes (0). The horizontal axis represents continuous time $(t)$ and the vertical axis the logarithm of the GDP as a function of time $f(t)$. In addition, $\tau$ represents each moment in time between zero and time T. $P$ represents the peak of the expansion. ${ }^{23}$

\footnotetext{
${ }^{18}$ See Harding and Pagan (2002) and Hamilton (1989) for a debate about the two business cycle dating methods. For a comparison of different business cycle dating methods, see Layton and Katsuura (2001) and Chauvet and Piger (2008).

${ }^{19} \mathrm{We}$ also compute the US business cycle to have a consistent estimation of turning points. Although very similar, it does not exactly match the NBER official dating. The main difference is that using the BB method, the early 2000s recession is not identified.

${ }^{20}$ An expansion runs from the first period after the trough to the following peak.

${ }^{21}$ We are not able to identify the business cycle of four countries (Colombia, India, Poland and Saudi Arabia), due to the short length and idiosyncrasy of these data series.

${ }^{22}$ The detailed tables of expansion dates for each country are available upon request.

${ }^{23}$ See Gadea et al. (2017) for a graphical illustration.
} 
Regarding the traditional measures, Harding and Pagan (2002) proposed four measures to examine the two business cycle phases once turning points have been dated. As in this paper we focus on expansions, the measures are described as follows.

1. Duration: the time spent between the trough and the following peak. It is measured in quarters.

$$
D=\overline{0 T}
$$

2. Amplitude: it compares the log level of GDP between the trough and the peak.

$$
A=\overline{0 P}
$$

3. Cumulation: it refers to the cumulated gain or loss and consists of the sum of the amplitudes of each cyclical phase or total area described by the GDP in logs.

$$
C=\int_{0}^{T} f(t) d t
$$

4. Excess: the difference between the actual area drawn by the path of the log of the GDP and the hypothetical path if the transition between two consecutive turning points was linear. A positive Excess (concave path) is characterized by a recovery that starts with a high growth rate that subsequently smoothens, whereas a negative Excess (convex path) means that the opposite happens. Excess is zero if the growth is linear over the expansion.

$$
E=\int_{0}^{T} f(t) d t-(\overline{0 T} * \overline{0 P}) / 2
$$

The shape of actual expansions does not have a clear stylized form (concave, convex or linear), so we also use the shape-related measures of Gadea et al. (2017). These measures identify the evolution of the pattern of the expansions more comprehensively and are useful to compare stylized facts of different expansions at different moments of time. From the different measures they propose, we focus on those related to the early stages of expansions (the first and the second measure), to the middle of the expansionary path (the third and the fourth measures) and the time needed to recover the GDP level previous to the recession (the last one):

1. Early shape: the number of consecutive positive excesses at the beginning of the expansion or minus the number of consecutive negative excesses at the beginning of the expansion, in relation to the total duration of the expansion. ${ }^{24}$

${ }^{24}$ Notice that a pointwise excess, $E_{t}$, is the excess at each point in time $t=1,2, \ldots \tau \ldots T$, that is,

$$
E_{t}(\tau)=\int_{0}^{\tau} f(t) d t-(\overline{0 \tau} * \overline{0 l(\tau)}) / 2
$$




$$
\text { Early shape }=\frac{\tau^{E S}}{\overline{0 T}}
$$

where

$$
\tau^{E S}=\left\{\begin{array}{ll}
i & \text { if } E_{t}(j)>0 \forall j<i \\
-i & \text { if } E_{t}(j)<0 \forall j<i
\end{array},\right.
$$

with $i \in N$.

2. Inshape: the number of consecutive periods with $E_{t}$ positive and $\Delta E_{t}$ positive or minus the number of consecutive periods with $E_{t}$ negative and $\Delta E_{t}$ negative. It measures changes in the shape, from concave to convex or the opposite.

$$
\text { Inshape }=\frac{\tau^{I}}{\overline{0 T}}
$$

where $\tau^{I}$ is " $i$ " such that $E_{t}(i)>0$ and $\Delta E_{t}(i)>0 \forall i$ and " $-i$ " so that $E_{t}(i)<0$ and $\Delta E_{t}(i)<0 \forall i$.

3. Half life: number of periods $\tau$ needed to obtain half of the cumulation, relative to the total duration. A value of $\frac{1}{\sqrt{2}}$ is equivalent to a linear path. The higher the value, the longer it takes to recover the half of the total area.

$$
\text { Half life }=\frac{\tau^{H L}}{\overline{0 T}}
$$

so that $C\left(\tau^{H L}\right)=C(T) / 2$.

4. Medium area: area obtained in the middle of the duration of the expansion in relation to a hypothetical triangle. A value of 1 implies a linear path. A value below (above) 1 means that the rate of growth is slower (quicker) than linear.

$$
\text { Medium Area }=4 \frac{\operatorname{Area}(\overline{0 T} / 2)}{\overline{0 T} * \overline{0 P} / 2}
$$

5. Time-to-recovery: number of periods to recover the level of GDP previous to the recession in relation to the total duration of the expansion.

$$
\text { Time-to-recovery }=\frac{\tau^{W}}{\overline{0 T}}
$$

where $\tau^{W}$, so that $f_{t}\left(\tau^{W}\right)=f_{t}\left(P_{-1}\right)$, and $P_{-1}$ is the peak of the previous expansion.

Notice that, by definition, the higher the values of duration, cumulation, amplitude, excess, early shape, inshape and medium area and the lower the value of half life is, the wealthier the expansion is. In the case of time-to-recovery the interpretation is not so straightforward since (i) it depends on how deep was the previous recession, i.e., if it was 
smooth it will take less to recover the previous level of the GDP than if it was deep and (ii), this is a relative measure and while we could think that it would be better to recover quickly, this measure is not able to account for what happens after the GDP level previous to the recession is reached.

We compute the four traditional measures and the five shape-related measures for each expansion of every country in our sample. ${ }^{25}$ It has to be borne in mind that the average value at the country level may mask quite different expansions both within and across countries.

Figure 3 shows the average value of the "traditional" measures for every country. There is a high degree of heterogeneity across them. For instance, while the average Duration of an expansion for all the countries in our sample is almost 26 quarters, Korea has the longest expansion on average (74 quarters) while Argentina has the shortest one (11 quarters). In terms of Excess, some countries are characterized by their convex average expansions, while in some others, they are concave. In convex expansions, actual paths show gradual changes in the slope at the beginning of the phase, but they become steeper as the end of the phase comes, as in Latvia or Slovenia. On the contrary, in concave expansions, actual paths start the phase of the cycle with steep changes and end the phase smoothly. For instance, Japan and Slovakia have the most concave expansions on average.

Concerning the shape-related measures, Figure 4 displays the average value of each of the five measures for every country. Early shape and Inshape have average values of -0.01 and -1.4, respectively. So, the average behavior of GDP at the beginning of the expansion is not very steep. However, there is a high degree of heterogeneity. For instance, if we focus on Inshape, there are some countries, such as Korea and Chile, in which expansions show positive excesses at the beginning and which continuously accelerate. The results on Half life, a measure that gives us information about the middle path of the phase, are more homogeneous across countries. A value of 0.11 indicates that expansions in our sample could be considered relatively fast on average. In the same line, the number of periods to recover the level of GDP previous to the recession in relation to the total duration of the expansion (Time-to-recovery), is relatively low, but there are some exceptions. For instance, we observe that Austria is the country where the GDP recovered its previous level most rapidly, whereas Cyprus shows the slowest recovery.

\subsection{Cross-country multiple regressions}

We have identified expansions of a wide set of countries, both developed and developing. Then, we have characterized every single expansion of each country individually, with the measures described in the previous subsection. In this subsection, we aim at analyzing the role played by external imbalances on how an economy recovers from a recession.

\footnotetext{
${ }^{25}$ The detailed tables of expansion features for each country are available upon request.
} 
For this purpose, we have calculated some indicators, to capture the effects of external imbalances on recoveries, taking into account that these effects need not be contemporaneous. For instance, what affects the way an economy recovers from a recession may be the imbalances accumulated during the previous years, during the previous recession or expansion or even the trend that they have shown before the expansion. The definition of an external disequilibrium according to the European Commission's Macroeconomic Imbalance Procedure or its persistence may also influence expansions. Hence, we define a set of variables to try to capture the way external imbalances influence recoveries and expansions. We have classified these variables into those defined for the current account balance and those based on the NFA position. In addition, a first group of each of them are related to the initial conditions (before the current expansion) and a second one refer to the conditions during the expansions.

Regarding the current account balance (CA), we have proposed the following variables:

1. Group 1: Initial-conditions variables

(a) CA1: average CA/GDP in the previous year to the current expansion.

(b) CA2: average CA/GDP in the two years previous to the current expansion.

(c) $C A 3$ : average $C A / G D P$ in the three years previous to the current expansion.

(d) CA4: average CA/GDP in the four years previous to the current expansion.

(e) CA5: average CA/GDP during the previous recession.

(f) CA6: average CA/GDP during the previous expansion.

(g) CA7: the sign of CA/GDP. This is a categorical variable that takes the following values:

- 1 if $\mathrm{CA} / \mathrm{GDP}$ is positive the previous 4 years.

- -1 if it is negative the previous 4 years.

- 0 otherwise (that is, if during the previous 4 years, some of them present surplus and others deficit)

(h) CA8: acceleration of CA/GDP. This is a categorical variable that takes the following values:

- 1 if CA/GDP is positive and has progressively increased during the previous 4 years

- 2 if it progressively improves starting from a deficit

- -1 if it is negative and has progressively worsened during the previous 4 years

- -2 if it worsens starting from a surplus

- 0 otherwise

(i) CA9: dummy variable to indicate a CA external imbalance as defined by the MIP criterion, that is, a value of CA/GDP below $-4 \%$ or above $6 \%$ in the previous year 
(j) CA10: persistence of the previously defined imbalance in $C A 9$. It takes value 1 if the disequilibrium takes place in the 4 previous years.

2. Group 2: Intra-expansion variables:

(a) CA11: average CA/GDP during the current expansion.

(b) CA12: average CA/GDP during the current recovery (first year of the current expansion).

(c) CA13: average CA/GDP during the last year of expansion.

(d) CA14: prevalence of positive disequilibrium, measured as percentage of quarters with a positive value (surplus). Note that a symmetric definition would be the prevalence of negative disequilibrium, percentage of quarters with a negative value (deficit).

(e) CA15: behavior during the expansions. A categorical variable that takes the following values:

- 6: if it starts from a surplus and it increases during the expansion.

- 5: if starting from surplus, the latter is reduced during the expansion.

- 4: if it starts from a deficit that improves.

- 3: if starting with a deficit, turns into a surplus at the end of the expansion.

- 2: if it is negative and worsens.

- 1: if the current account ends in deficit starting from surplus.

Concerning the net foreign assets position (NFA), we define the following variables:

1. Group 1: Initial conditions variables

(a) NFA1: average NFA/GDP in the year previous to the current expansion.

(b) NFA2: average NFA/GDP in the two years previous to the current expansion.

(c) NFA3: average NFA/GDP in the three years previous to the current expansion.

(d) NFA4: average NFA/GDP in the four years previous to the current expansion.

(e) NFA5: average of NFA/GDP during the previous recession.

(f) NFA6: average of NFA/GDP during the previous expansion.

(g) NFA7: sign of NFA/GDP. A categorical variable that takes the following values:

- 1 if NFA/GDP is positive the previous four years.

- -1 if it is negative the previous four years.

- 0 otherwise (when it alternates between a positive and a negative position).

(h) NFA8: acceleration of NFA/GDP position. A categorical variable that takes the following values: 
- 1 if NFA/GDP is positive and has progressively increased during the previous 4 years.

- 2 if it progressively improves starting from a debtor position.

- -1 if it is negative (debtor position) and has progressively worsened during the previous 4 years.

- -2 if it worsens starting from a creditor position.

- 0 otherwise

(i) NFA9: a dummy variable to detect a NFA external imbalance as defined by the MIP criterion, that is, a value of NFA/GDP below $-35 \%$ in the previous year (that is, net debtor position over 35\%).

(j) NFA10: persistence of the previously defined imbalance. It takes the value 1 if there has been an imbalanced position during the last 4 years.

(k) NFA11: intensity of NFA/GDP in the previous year. A categorical variable that takes the following values

- 0 if the average NFA/GDP is $>0$

- 1 if $N F A / G D P<0$ and $|N F A / G D P| \leq 0.5$

- 2 if $N F A / G D P<0$ and $0.5<|N F A / G D P| \leq 1$

- 3 if $N F A / G D P<0$ and $|N F A / G D P|>1$

2. Group 2: Intra-expansion variables

(a) NFA12: average NFA position during the current expansion.

(b) NFA13: average NFA position during the current recovery (first year of current expansion).

(c) NFA14: average during the last year of the expansion.

(d) NFA15: behavior during the expansions. This categorical value takes the following values:

- 6: if coming from a creditor position, it increases during the expansion.

- 5: if starting from a creditor position, it worsens during the expansion.

- 4: if it starts in a debtor position that turns into creditor at the end of the expansion.

- 3: if the NFA starts from a debtor position but improves during the expansion.

- 2: if NFA ends in a debtor position starting from a creditor one.

- 1: if it is debtor and worsens. 
We are using categorical as well as dummy variables among the set of exogenous regressors. As an example of such categorical variables, we compute NFA15 as follows ${ }^{26}$ : we assign a number from 6 to 1 depending on the evolution of the NFA position during the expansions. The number of expansions may vary depending on the country. Larger values of the categorical variable are related to creditor or improving situations, whereas smaller values represent a deterioration of the NFA position.

We compute these 30 measures of external imbalances associated to each expansion of each country in our sample.

Once we have all the ingredients (each expansion individually identified, the traditional and shape-related measures computed for each individual expansion and also the variables of external imbalances), we are able to analyze the effects of external imbalances on the characteristics of expansions and recoveries. To that end, we carry out a cross-country multiple regression analysis:

$$
C_{i j}^{k}=x_{i j}^{\prime} \beta+z_{i j}^{\prime} \delta+u_{i j}
$$

where $C_{i j}^{k}$ denotes the endogenous variables $k=1 \ldots m, x_{i j}^{\prime}$ is a vector representing several exogenous variables and $z_{i j}^{\prime}$ collects the control variables.

The estimation strategy adopted is focused on testing the hypotheses formulated in Section 2. The first hypothesis is that expansions and recoveries are weaker when the economies suffer from external imbalances. Thus, the estimation of equation (12) relates the expansions and recoveries characteristics with different measures of imbalances. Regarding the endogenous variables $C_{i j}^{k}$, we consider nine measures of the expansion features. Specifically, the four traditional measures of Harding and Pagan (2002) (duration, amplitude, cumulation and excess) and the shape-related measures of Gadea et al. (2017) (early shape, inshape, half life, medium area and time-to-recovery).

Concerning the exogenous variables, we use two different sets of indicators representing the external position of an economy, also related to the second hypothesis to be tested: whether stock or flow variables are more relevant to explain the characteristics of recoveries and expansions. For this reason, we run two different groups of regressions. First, we consider the fifteen current account indicators $(C A 1, \ldots, C A 15)$ as the explanatory variables. In the second, we include the net foreign assets variables $(N F A 1, \ldots, N F A 15)$ as the explanatory variables in our framework.

Note that the resulting specification has a cross-sectional structure and, consequently, we can apply standard techniques of estimation, such as OLS. However, the database is not a simple cross-section, as we have as many observations by country as the number of

\footnotetext{
${ }^{26}$ The same interpretation can be given to $C A 15$ in the case of the current account deficit or surplus.
} 
expansions that we obtain using our dating techniques. Moreover, we correct the possible existence of heteroskedasticity in our estimation by HAC methods. ${ }^{27}$

Finally, there are some variables that could help assessing or clarifying the relationship between external imbalances and recoveries. In order to deal with the problems associated with country heterogeneity, we have introduced control variables in the cross-country regressions. In Tables 2-3 and 5-6 the estimated parameters are the result of controlling for a the following group of variables:

- Geography: a dummy variable defined for groups of countries following the World Bank region classification. The groups are "East Asia and Pacific", "Europe and Central Asia", "Latin America and Caribbean", "Middle East and North Africa", "North America", "South Asia" and "Sub-Saharan Africa", labeled respectively as 1, 2, 3, 4, 5, 6 and 7.

- Income: a dummy variable defined for groups of countries according to their income and following the World Bank income group classification. The groups are "High income", "Lower middle income" and "Upper middle income", which are labeled as 1,2 and 3.

- Trade openness: degree of openness of a country the year previous to the expansion, defined as the sum of exports and imports as a percentage of GDP. Source: World Bank.

- Exchange rate regime: we are using the "coarse" classification of Ilzetzki et al. (2017), where 1 corresponds to fixed and pegged exchange rate regimes, 2 to crawling pegs, 3 to managed float, 4 to free floating, 5 to freely falling and 6 to dual market regimes.

- Financial development: measured as deposit money bank assets to bank assets in percentage. This indicator has been obtained from the "Financial Development and Structure Dataset" in its June 2017 update. It can be accessed through the World Bank and was created by Beck et al. (2000).

- Financial openness: We use the Chinn and Ito (2006) index of financial integration.

- Oil prices: it has been obtained from FRED (https: / / fred.stlouisfed.org) and has been computed as deflated Texas Spot crude oil price.

\footnotetext{
${ }^{27}$ The usual assumption that the errors are iid can be violated in some cases. Thus, heteroskedasticity can be tested by assuming the presence of clustered errors, i.e. observations within group $i$ are correlated in some unknown way, inducing correlation in errors within $i$, but groups $i$ and $j$ do not have correlated errors. In the presence of clustered errors, OLS estimates are still unbiased but standard errors may be quite wrong. Taking this into account, we have checked that our results are robust to clustering standard errors with intensity of NFA/GDP and also with some variables of control, such as the exchange rate regime.
} 
- Labor market regulation index: a synthetic variable that summarizes different measures of labour market regulation from CBR Leximetric Datasets by Adams et al. (2016). We have computed the average of all the proposed indicators.

- Type of crises: From the database of Laeven and Valencia (2018) we have built 3 dummy variables that take value 1 if in the previous recession there was a banking, currency or debt crisis, respectively.

In order to provide a quick visual inspection of the variables "Geography" and "Income" we have included two maps in Figure

In Figure 6 we can observe the evolution of openness for the whole sample of countries. As in the other cases, warmer colours correspond to a larger value of the variable. In this case, a higher degree of openness. The smaller EU members have evolved during the sample period towards a $100 \%$ of openness, whereas larger EU countries and, in general, large economies, such as the US, Japan or the UK, are more closed economies. The general trend through the time span in the sample has been an increase in openness. However, the degree of heterogeneity is remarkable.

A more detailed description of the variable exchange rate regime can be gained from the heat map in Figure 7. Relatively fixed exchange rate regimes are represented using the cooler colours, that is, in blue, where crayola blue stands for fixed exchange rates, currency boards and narrow-band pegged systems; ice blue corresponds to crawling pegs; in light green, managed floats and in yellow floating regimes; finally, orange free falling and, in red, dual market regimes. Non available data are in ultramarine blue. At the world level, the majority of the exchange rate regimes are free or managed floating. However, our sample has a large number of OECD countries and EA members. Although the exchange rate of the euro floats, Eurozone member countries appear in crayola blue (no flexibility) since their entry in the monetary union, as described in Ilzetzki et al. (2017). During the European Monetary System, Germany is considered in a free floating regime and the other member countries in a pegged system, or regime 2 (ice blue) or 3, depending on the percentage of the band. The Bretton Woods years are also in crayola blue for all its members. In managed floating regimes are currently many OECD countries such as Turkey, Sweden, Mexico, Korea, Israel or Iceland, that are considered not to have an anchor currency, whereas Australia, the UK, the US and Japan are all in yellow, that is, free floating.

The evolution of financial development is in sharp contrast to the previous variable. Looking at its evolution in the heat map shown in Figure 8, the majority of the countries with data available have reached the highest level of financial development ${ }^{28}$. For those with data available, some exceptions (that end the sample below 100\%) are Argentina, Ireland, Japan and the US.

\footnotetext{
${ }^{28}$ Even if we include 46 countries in our analysis the majority are relevant players in the world economy.
} 
Figure 9 is complementary to Figure 8, as it depicts the calendar of financial liberalization in the countries in our sample. Cold colours (dark blue) represent a low degree of financial openness, whereas dark red stands for the highest level of openness. With data available since the seventies for most countries, a first group that stands out are the members of the EA, that decreed free capital mobility at the beginning of the nineties. Also other EU members, such as Sweden, adopted this measure in the mid-nineties and the UK much earlier, in the eighties. A second group consists of large OECD economies (the US, Japan and Canada) that had already very open financial markets at the beginning of the sample and, to a lesser extent, New Zealand and Australia. Poland, that joined the EU some 15 years ago, has only recently advanced towards liberalization. Finally, emerging countries such as India, Brazil, South Africa and Argentina have still significant barriers.

An additional control variable that may play an important role in the analysis is the real oil price, shown in Figure 10. This variable, an international price of a key commodity, will have different effects on the countries analyzed depending on the degree of oil dependence.

The evolution of the Labour market regulation index of Adams et al. (2016) is represented using a heat map in Figure 11. Cold colours (and low values of the index) represent a low degree of regulation, while warmer colours designate the highly regulated labour markets. Non-available observations are zeros and, therefore, dark-blue. Only a few countries (Australia, Canada, New Zealand, Saudi Arabia, the US and, to a lesser extent, the UK) have a deregulated labour market. In intermediate positions are Switzerland, South Africa, Japan, Israel, Denmark, Costa Rica, Colombia and Chile. The rest are midly or highly regulated. The most regulated labour markets are in Europe: Portugal, France, the Netherlands, Italy, Slovenia, Spain and Sweden. Also the most recent EU members maintain a significant degree of restrictions, such as Poland, Latvia or Lithuania.

Concerning the classification of crises of Laeven and Valencia (2018), of the total of 259 expansions considered in the sample, $42(16 \%)$ of them are preceded or have suffered in their course an episode of banking crisis, 28 (11\%) of currency crisis and $13(5 \%)$ of debt crisis. Figure 12 summarizes this information and attribute the episodes to the countries in our sample. Four of them have suffered the three types of crises during their expansions: Argentina, Cyprus, Israel and New Zealand. The rest have had, linked to their expansions, banking crises and, sometimes, currency crises. Debt crises are less frequent, probably because public revenue increases during the expansions and this prevents the accumulation of debt. Chile is the most prominent exception. Finally, Australia, Canada, Costa Rica, Ireland, Japan, the Netherlands, Slovenia and Spain do not have any crisis during the expansions in our sample.

The use of these control variables allows us to capture the heterogeneity inherent to the countries in the sample and concentrate on the effect that the different measures of the current account and the NFA position played in the business cycle characteristics of the expansions 
footnoteWe present in table A1 the descriptive statistics not only of the control variables, but also those of the endogenous and exogenous variables.. According to Broner and Ventura (2016), some country characteristics, such as those represented by the factors above, may determine the effect that financial globalization has in the economy. This type of variables are not normally included in standard models, but have been showed to have an effect on the direction and intensity of financial flows. Therefore, in order to capture the role of external imbalances on the speed and extent of the recoveries, we have controlled for region, income, trade and financial openness, exchange rate regime, degree of financial development, the real oil price, the degree of labor market regulation and the existence of crises during the expansions of the countries in the sample.

\section{Discussion of the results}

In this Section we present the results of our cross-country multiple regressions to analyze the role played by external imbalances on the characteristics of recoveries for a large sample of countries. In our strategy to test $H_{1}$ and $H_{2}$ as formulated at the end of Section 2, the business cycle characteristics of the expansions are endogenous variables in the crosscountry multiple regressions, whereas the explanatory variables consist of different measures of the external imbalances. In particular, these measures are calculated for both the current account deficit (flow approach) and the net foreign asset position (stock approach) as a percentage of GDP. ${ }^{29}$ We regress every single expansion feature of each country on the external imbalance measures associated to all the countries in the sample.

The parameters obtained in the cross-country multiple regressions for the current account characteristics are presented in tables 1,2 and 3. The parameters shown in Table 1 correspond to the regressions that do not include any control variable, whereas Table 2 includes the results when we introduce all the controls and select the significant ones using a general to specific approach. As a robustness check, we have also selected the controls that maximize the number of significant explanatory variables in each regression and the results are presented in Table 3. Tables 4, 5 and 6 are the results for the NFA version of the imbalances. In all cases, in order to avoid the effects of multiple hypotheses testing we have corrected the p-values of the statistics using the Bonferroni method.

The first results are obtained for the CA without control variables. In Table 1 , only measure CA5 (the average CA over GDP during the previous recession) affects the amplitude of the recovery negatively. This means that cumulating a positive external imbalance during a recession negatively influences the length of the subsequent expansion. ${ }^{30}$ Other mea-

\footnotetext{
${ }^{29}$ The measures have been described above but we will make additional references to them in the present subsection.

${ }^{30}$ The results with CA5 are heavily influenced by two atypical values. The Australian expansion of 1991.1, which lasted more than 100 quarters, preceded by a CA5 of $-4.9 \%$, and the high negative value of CA5 before the Icelandic expansion of 1995.3-2007.4 (-16.7\%).
} 
sures in Table 1 were also significant but lost their relevance once we used the Bonferroni correction.

We then carry out the estimation with the nine control variables. The results are presented in Tables 2 and 3. Concerning the general to specific selection results (Table 2), the CA-GDP ratio has a negative effect on the time-to-recovery up to four years before the current expansion, as $C A 1, C A 2, C A 3$ and $C A 4$ are significant. In addition, the average value of this ratio during the previous expansion $(C A 6)$ has a negative effect. If we look at the details of our estimation, the negative sign found in all the parameters implies that a current account deficit would shorten the time to return to the previous GDP level. In this case, all the significant measures correspond to the first group or "initial conditions" variables. When we select the control variables that maximize the number of significant exogenous variables, we find that $C A 5$ and $C A 15$ are significant to explain the amplitude of the expansion, whereas only $C A 15$ is significant for its duration. Finally, $C A 9, C A 12$ and $C A 15$ explain the time-to-recovery. In this case, both initial conditions and intra-expansion variables turn out to be significant. The duration of the expansion decreases with the improvement of the current account balance during the expansion itself (CA15). The amplitude is also reduced with $C A 15$ and with the average of the last four years balance of the current account. We should stress that $C A 15$ is an intra-expansion measure and captures the evolution of the current account during the current expansion. As the majority of the countries in our sample are very open financially, expansions are financed, very frequently, through external sources. Hence, a deterioration of the current account balance should be expected at the end of the expansion. The same would apply to the NFA position, the stock version of the current account. Bearing this in mind, the time-to-recovery increases if the current account suffers an important imbalance, according to the EU scoreboard of the Macroeconomic Imbalance Procedure, as measured by $C A 9$. In contrast, a positive balance during the recovery ( $C A 12$ ) would shorten the time to recover the initial GDP level. Lastly, $C A 15$ has a positive sign, meaning that the improvement of the current account during the recovery increases the time-to-recovery.

In summary, independently of the approach taken regarding the control variables, the conclusions do not differ: the current account balance has a mixed behaviour during the expansions and recoveries, as GDP growth is frequently contemporaneous with a external balance deterioration. However, a strong imbalance, as captured by $C A 9$ clearly worsens the recovery.

Turning to the effects of the different measures of the Net Foreign Asset position on the characteristics of the recoveries, the first group of results is presented in Table 4, where the cross-country regressions are estimated without control variables. Although there are slight differences between the CA and the NFA definitions, we have tried to make them comparable and have followed the same ordering. 
In Table 4 we find, as in the case of the current account, that time-to-recovery is the business cycle characteristic that has more significant explanatory variables among the NFA measures. Also NFA15, the evolution of the NFA position during the expansion, is relevant for explaining duration, amplitude and cumulation. In these three cases, the sign is negative, so that if the expansion results in an improvement in the NFA position, the three expansion cycle characteristics would deteriorate. The reasoning, which also applies in the case of CA, has to do with the difference between the measures that capture the initial conditions (from NFA1 to NFA11 and those that are intra-expansions (NFA12 to NFA15). In this case, a higher value of NFA implies an improvement in the NFA position during the expansionary cycle, something that may restrict the quality of the expansion (reducing duration, amplitude and cumulation). In contrast, NFA5, the average NFA over GDP during the previous recession, has a positive effect in excess, as it implies that if the expansionary cycle starts from a healthy NFA position there is room to finance the expansion. Finally, NFA9, NFA10, NFA12, NFA14 and NFA15 explain time-to-recovery. The first two increase the periods needed to recover the GDP level previous to the recession, and mean that having a persistent macroeconomic imbalance in the NFA position makes recovery more lengthy. However, measures NFA12 and NFA14 point to a shorter time-torecovery when the average NFA position improves (either during the current expansion or during its last years). Higher values of NFA15 indicate that during the expansion the NFA position has improved and a positive sign in this parameter implies more time to recover.

When the cross-country regressions are run with the control variables (see 5 and 6 ), the pattern is quite similar: most of the NFA measures affect time-to-recovery. Table 5 presents the results of the regressions when the control variables have been selected using a general to specific approach. The existence of imbalances and their persistence, captured by measures NFA9 and NFA10 have a larger positive effect, making recoveries slower. Amplitude is negatively affected by NFA5, that is, the average NFA position in the previous recession, as well as the evolution of the balance during the expansion NFA15. The latter also has a negative effect on cumulation as in the previous cases.

When the control variables are selected to maximize the significant exogenous variables coefficients, half life and time-to-recovery are the two business cycle characteristics for which the NFA definitions are statistically significant (see Table 6). The type of behaviour they capture is similar and no relevant contradictory signs have been found in the direction of the effects. The first two measures, NFA1 and NFA2, are the NFA position one and two years before the current expansion. An improvement in the position would reduce the time-to-recovery and increase the half life of the expansion. The same applies to NFA3 and its negative sign in the time-to-recovery. NFA5, the average position during the previous recession would decrease the amplitude of the expansion and increase its excess. As for the measures related to the thresholds of the EU imbalance procedure, all three are significant (NFA9, NFA10 and NFA11), confirming previous results. The second group of measures 
(intra-expansion variables) turns out to be significant in some instances. NFA12, NFA13 and NFA14, or average NFA position during different phases of the current expansion, also increase the half life and reduce the time-to-recovery. Finally, NFA15 also has a negative effect on the duration, amplitude and cumulation of the expansion.

Summing up, half life and time-to-recovery, that is, the half life of the expansion and the time necessary to return to the GDP level previous to the recession, are the two measures most affected by external imbalances. When we consider the flow definition, that is, the current account (Tables 1 and 3), the persistence of imbalances and the disequilibrium according to the MIP were not significant (with one exception). The opposite is found when we analyze the effects of the stock variable, the NFA position: the larger and most significant effects have to do with the existence of persistent and large imbalances, independently of the inclusion of control variables or the method used for their selection.

\section{Concluding remarks}

A decade after the beginning of the recent Great Recession, flow external imbalances, such as the current account, have narrowed markedly. However, stock imbalances, such as NFA, have continued to increase and create challenges for future macroeconomic and financial stability. Early warning systems (scoreboards) have focused more on flow than on stocks variables. However, the results of this paper suggest that stock imbalances should be given a much more prominent role. Specifically, we find that the effect of CA imbalances measured at different periods in the business cycle and, more explicitly, its effects in the characteristics of the expansionary phase of the cycle seems to be relatively minor, except when the measures selected take into account the past evolution of the CA or are computed allowing for some degree of persistence. In contrast, the evolution of NFA seems to have much more explanatory power in terms of the time necessary to regain the level of output previous to the recession, as well as the amplitude and the cumulation of the recoveries. These results confirm the hypotheses formulated earlier: after we control for a large group of variables, the NFA position, as well as the persistence in current account imbalances, play a major role in the duration of expansions and the time-to-recovery. An implication of our results is that future macro-prudential policies should pay more attention to stock variables (such as the NFA position) when measuring the effects of external imbalances. Thresholds in the preventive arm of any alert system of indicators should be reinforced following the reform started by the Macroeconomic Imbalance Procedure introduced by the "Six-Pack" in the European Union. A further research topic worth investigating would be the role of possible asymmetries, that is, analyzing surpluses and deficits separately to assess whether they have a different impact on GDP expansions. 


\section{References}

Adams, Z., Bishop, L., and Deakin, S. (2016). CBR Labour Regulation Index. Technical report, Centre for Business Research, Cambridge.

Aizenman, J., Pinto, B., and Sushko, V. (2013). Financial sector ups and downs and the real sector in the open economy: Up by the stairs, down by the parachute. Emerging Markets Review, 16(1):1-30.

Baldwin, R. and Giavazzi, F. (2015). The Eurozone Crisis. A Consensus View of the Causes and a Few Possible Solutions. CEPR Press, London.

Ball, L. (2014). Long-Term Damage from the Great Recession in OECD Countries. Technical Report 20185, National Bureau of Economic Research, Cambridge, MA.

Beck, T., Demirguc-Kunt, A., and Levine, R. (2000). A New Database on the Structure and Development of the Financial Sector. The World Bank Economic Review, 14(3):597-605.

Bernanke, B. and Gertler, M. (1990). Financial Fragility and Economic Performance. The Quarterly Journal of Economics, 105(1):87-114.

Blanchard, O. (2015). Are Capital Inflows Expansionary or Contractionary? Theory, Policy Implications, and Some Evidence. Nber Working Paper Series, 1(10909).

Bordo, M. D. and Haubrich, J. G. (2012). Deep Recessions, Fast Recoveries, and Financial Crises: Evidence from the American Record. SSRN Electronic Journal, pages 1-45.

Broner, F. and Ventura, J. (2016). Rethinking the Effects of Financial Globalization. Quarterly Journal of Economics, pages 1497-1542.

Bry, G. and Broschan, C. (1971). Cyclical Analysis of Time Series: Selected Procedures and Computer Programs. NBER, New York.

Burns, A. and Mitchell, J. (1946). Measuring business cycles. NBER, New York.

Caballero, R. J., Farhi, E., and Gourinchas, P.-O. (2008). An Equilibrium Model of Global Imbalances and Low Interest Rates. American Economic Review, 98(1):358-393.

Camarero, M., Carrion-i Silvestre, J. L., and Tamarit, C. (2013). Global imbalances and the intertemporal external budget constraint: A multicointegration approach. Journal of Banking and Finance, 37(12):5357-5372.

Camarero, M., Peiró-Palomino, J., and Tamarit, C. (2018). External imbalances and growth. Working Papers in Applied Economics, 8.

Catão, L. A. V. and Milesi-Ferretti, G. M. (2014). External liabilities and crises. Journal of International Economics, 94(1):18-32.

Cerra, V., Panizza, U., and Saxena, S. C. (2013). International evidence on recovery from recessions. Contemporary Economic Policy, 31(2):424-439.

Cerra, V. and Saxena, S. C. (2008). Growth Dynamics: The Myth of Economic Recovery. American Economic Review, 98(1):439-457.

Cerra, V. and Saxena, S. C. (2017). Booms, Crises, and Recoveries : A New Paradigm of the Business Cycle and Its Policy Implications. IMF Working Paper, 250. 
Chauvet, M. and Piger, J. (2008). A Comparison of the Real-Time Performance of Business Cycle Dating Methods. Journal of Business \& Economic Statistics, 26(1):42-49.

Checherita-Westphal, C. and Rother, P. (2012). The impact of high government debt on economic growth and its channels: An empirical investigation for the euro area. European Economic Review, 56(7):1392-1405.

Chinn, M. D. and Ito, H. (2006). What matters for financial development? Capital controls, institutions, and interactions. Journal of Development Economics, 81(1):163-192.

Claessens, S., Kose, M. A., and Terrones, M. E. (2012). How do business and financial cycles interact? Journal of International Economics, 87(1):178-190.

Darvas, Z. (2012). The limits of a purely intra-euro rebalancing strategy. VoxEU, (February):1-5.

Davis, J. S. (2014). Financial integration and international business cycle co-movement. Journal of Monetary Economics, 64:99-111.

De Grauwe, P. (2012a). Booms and busts in economic activity: A behavioral explanation. Journal of Economic Behavior and Organization, 83(3):484-501.

De Grauwe, P. (2012b). The Governance of a Fragile Eurozone. Australian Economic Review, 45(3):255-268.

Dias, D. A., Richmond, C., and Wright, M. L. (2014). The stock of external sovereign debt: Can we take the data at 'face value'? Journal of International Economics, 94(1):1-17.

Díaz-Alejandro, C. (1985). Good-bye financial repression, hello financial crash. Journal of Development Economics, 19(1-2):1-24.

European Commission (2018a). Economic Resilience in EMU. Quarterly Report on the Euro Area, 17(2):9-15.

European Commission (2018b). Financial cycle in euro area. Quarterly Report on the Euro Area, 17(2):17-30.

Evans, G. W. and Honkapohja, S. (2001). Learning and Expectations in Macroeconomics. Princeton University Press, Princeton, New Jersey.

Fagiolo, G., Napoletano, M., and Roventini, A. (2008). Are output growth-rate distributions fat-tailed? some evidence from OECD countries. Journal of Applied Econometrics, 23(5):639-669.

Gadea, M. D., Gomez-Loscos, A., and Perez-Quiros, G. (2017). Dissecting US recoveries. Economics Letters, 154:59-63.

Glick, R. and Rogoff, K. (1995). Global versus country-specific productivity shocks and the current account. Journal of Monetary Economics, 35(1):159-192.

Gourinchas, P. and Rey, H. (2014). External Adjustment, Global Imbalances, Valuation Effects. In Gopinath, G., Helpman, E., and Rogoff, K., editors, Handbook of International Economics, Volume 4, volume 4, chapter 10, pages 585-645. Elsevier B.V.

Gourinchas, P.-O. and Jeanne, O. (2013). Capital Flows to Developing Countries: The Allocation Puzzle. The Review of Economic Studies, 80(4):1484-1515.

Hamilton, J. D. (1989). A New Approach to the Economic Analysis of Nonstationary Time Series and the Business Cycle. Econometrica, 57(2):357-384.

Harding, D. and Pagan, A. (2002). Dissecting the cycle: a methodological investigation. Journal of Monetary Economics, 49(2):365-381. 
Ilzetzki, E., Reinhart, C. M., and Rogoff, K. S. (2017). Exchange Rate Arrangements Entering the 21st Century: Which Anchor Will Hold? NBER Working Paper Series, 23134.

IMF (2014). The Fund's Lending Framework and Sovereign Debt â Preliminary Considerations. Staff Report, (June).

IMF (2018a). Strong, Sustainable, and Balanced Growth Executive Summary. G-20 Report, (October).

IMF (2018b). Tackling Global Imbalances and Rising Trade Tensions. World Economic and Financial Surveys. External Sector Report.

Jordà, Ò. (2014). Assessing the historical role of credit: Business cycles, financial crises and the legacy of Charles S. Peirce. International Journal of Forecasting, 30(3):729-740.

Jordà, Ò., Schularick, M., and Taylor, A. M. (2011). Financial Crises, Credit Booms, and External Imbalances: 140 Years of Lessons. IMF Economic Review, 59(2):340-378.

Jordà, Ò., Schularick, M., and Taylor, A. M. (2015). Sovereigns versus Banks: Credit, Crises, and Consequences. Journal of the European Economic Association, 00(0):n/a-n/a.

Kiyotaki, N. and Moore, J. (1997). Credit Cycles. Journal of Political Economy, 105(2):211-248.

Korinek, A. (2011). Foreign currency debt, risk premia and macroeconomic volatility. European Economic Review, 55(3):371-385.

Laeven, L. and Valencia, F. (2018). Systemic Banking Crises Revisited. IMF Working Papers, 18(206):1.

Lane, P. R. and Milesi-Ferretti, G. M. (2001). The external wealth of nations: Measures of foreign assets and liabilities for industrial and developing countries. Journal of International Economics, 55(2):263-294.

Lane, P. R. and Milesi-Ferretti, G. M. (2007). The external wealth of nations mark II: Revised and extended estimates of foreign assets and liabilities, 1970-2004. Journal of International Economics, 73(2):223-250.

Layton, A. P. and Katsuura, M. (2001). Comparison of regime switching, probit and logit models in dating and forecasting US business cycles. International Journal of Forecasting, 17(3):403-417.

Mayer, T. (2011). Euroland 's hidden balance-of- payments crisis. Deutsche Bank Research, (October).

Mendoza, E. G., Quadrini, V., and Ríos-Rull, J.-V. (2009). Financial Integration, Financial Development , and Global Imbalances Vincenzo Quadrini. Journal of Political Economy, 117(3):371-416.

Mendoza, E. G. and Smith, K. A. (2006). Quantitative implications of a debt-deflation theory of Sudden Stops and asset prices. Journal of International Economics, 70(1):82-114.

Milesi-Ferretti Assaf, G. M. . R. (1996). Current account sustainability: Selected east Asian and Latin American experiences.

Pattillo, C., Poirson, H., and Ricci, L. A. (2011). External Debt and Growth. Review of Economics and Institutions, 2(3):1-30.

Sargent, T. J. (1993). Bounded Rationality in Macroeconomics. Oxford University Press.

Schmitt-Grohé, S. and Uribe, M. (2018). Multiple Equilibria in Open Economy Models with Collateral Constraints: Overborrowing Revisited. Mimeo, (April 2016).

Sutherland, D. and Hoeller, P. (2012). Debt and Macroeconomic Stability: An Overview of the Literature and Some Empirics. Technical Report 1006. 


\section{Tables}

Table 1: Effect of external position (CA/GDP) on characteristics of recoveries

\begin{tabular}{|c|c|c|c|c|c|c|c|c|c|c|c|c|c|c|c|}
\hline Endogenous/Exogenous & $\overline{\mathrm{CA} 1}$ & CA2 & CA3 & CA4 & CA5 & CA6 & CA7 & CA8 & CA9 & CA10 & CA11 & CA12 & CA13 & CA14 & CA15 \\
\hline Duration & -0.0 & -0.06 & 8 & 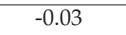 & -0.50 & -0.18 & -2.85 & 2.49 & -2.02 & -2.9 & -0.1 & 0 & -0. & -3.79 & -0.28 \\
\hline & 0) & 0) & 0) & 0.93 & 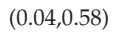 & $(0.64$, & $(0.25$, & & 10) & & & & & & \\
\hline Amplitude & $\begin{array}{l}-0.00 \\
35.1 .0\end{array}$ & $\begin{array}{c}-0.00 \\
(0.33 .1 .00\end{array}$ & $\begin{array}{c}-0.00 \\
(0.361 .00\end{array}$ & $\begin{array}{c}-0.00 \\
(0.35 .1 .00\end{array}$ & $\begin{array}{c}-\mathbf{- 0 . 0 1} \\
(0.000 .0\end{array}$ & $\begin{array}{c}-0.00 \\
(0.261 .00\end{array}$ & $\begin{array}{c}-0.04 \\
(0.080 .91)\end{array}$ & $\begin{array}{l}0.03 \\
03.0 .4\end{array}$ & $\begin{array}{c}-0.01 \\
.71 .1 .00)\end{array}$ & $\begin{array}{l}-0.03 \\
.571 .00)\end{array}$ & $\begin{array}{l}-0.01 \\
.171 .00)\end{array}$ & $\begin{array}{l}-0.01 \\
.151 .00)\end{array}$ & $\begin{array}{l}-0.01 \\
.060 .67)\end{array}$ & $\begin{array}{c}-\mathbf{- 0 . 1 2} \\
(0.00,0.03)\end{array}$ & $\begin{array}{l}-0.01 \\
34.1 .00)\end{array}$ \\
\hline Cumulation & -0.1 & $\begin{array}{r}-0 . \\
0.25\end{array}$ & -0. & -0. & -0. & -0. & $\begin{array}{r}-1 . \\
0.06\end{array}$ & 1. & -0 & -0 & -0 & -0 & & & \\
\hline Excess & & & & & & -0.8 & -0 & & -0.10 & -0.0 & & & & & 10) \\
\hline $\mathrm{Ea}$ & $\begin{array}{r}0.6 \\
(0.57,\end{array}$ & 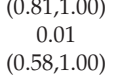 & $\begin{array}{r}0 . \\
0.55\end{array}$ & 0 & $\begin{array}{r}0 \\
\left(0.4 c^{2}\right.\end{array}$ & $(0$. & $(0$ & & 0 & 0) & & $\begin{array}{l}.00) \\
.00) \\
.00\end{array}$ & $\begin{array}{l}.00) \\
.00)\end{array}$ & & $\begin{array}{l}1.00) \\
8 \\
8.899)\end{array}$ \\
\hline Inshape & & 0. & 0. & 0. & $\begin{array}{r}0 . \\
(0.23\end{array}$ & ( & (0.7 & $(0.9$ & $\begin{array}{r}0 . \\
(0.75\end{array}$ & 0. & $\begin{array}{r}0 \\
0.31\end{array}$ & & & & $(0.1$ \\
\hline Half life & 0.00 & $\begin{array}{l}0.00 \\
0.11,1.0\end{array}$ & 0.00 & $\begin{array}{r}0.0 \\
(0.45,1\end{array}$ & $\begin{array}{c}-0.00 \\
(0.43,1.00)\end{array}$ & $\begin{array}{c}0.00 \\
(1.00,1.0\end{array}$ & $\begin{array}{c}-0.00 \\
(0.88,1.00)\end{array}$ & $\begin{array}{c}0.01 \\
(0.39,1.00)\end{array}$ & $\begin{array}{c}-0.00 \\
(0.92,1.00)\end{array}$ & $\begin{array}{c}-0.02 \\
(0.41,1.00)\end{array}$ & $\begin{array}{c}0.00 \\
(0.34,1.00)\end{array}$ & $\begin{array}{c}0.00 \\
(0.35,1.00)\end{array}$ & $\begin{array}{c}0.00 \\
(0.62,1.00)\end{array}$ & $\begin{array}{c}0.01 \\
(0.64,1.00)\end{array}$ & $\begin{array}{c}-0.00 \\
(0.63,1.00)\end{array}$ \\
\hline Medir & $\begin{array}{c}-0.00 \\
(0.86,1.00)\end{array}$ & $\begin{array}{c}-0.00 \\
(0.63,1.00)\end{array}$ & $\begin{array}{r}-0 . \\
(0.47\end{array}$ & $\begin{array}{r}-0 \\
(0.42\end{array}$ & $\begin{array}{r}-0 . \\
(0.83,\end{array}$ & $\begin{array}{r}-0 . \\
(0.82\end{array}$ & $\begin{array}{c}-0.02 \\
(0.76,1.00)\end{array}$ & $\begin{array}{c}0.03 \\
(0.45,1.00\end{array}$ & $\begin{array}{c}-0.04 \\
(0.74,1.00)\end{array}$ & & & & & & $\begin{array}{c}0.03 \\
(0.24,1.00)\end{array}$ \\
\hline Tir & $\begin{array}{c}-0.02 \\
(0.04,0.51)\end{array}$ & $\begin{array}{c}-0.02 \\
(0.03,0.35)\end{array}$ & $\begin{array}{c}-0.02 \\
(0.01,0.21)\end{array}$ & $\begin{array}{c}-0.02 \\
(0.01,0.21)\end{array}$ & $\begin{array}{c}-0.00 \\
(0.65,1.00)\end{array}$ & $\begin{array}{c}-0.01 \\
(0.08,0.88)\end{array}$ & $\begin{array}{c}-0.04 \\
(0.40,1.00)\end{array}$ & $\begin{array}{c}-0.02 \\
(0.55,1.00)\end{array}$ & $\begin{array}{c}0.07 \\
(0.41,1.00)\end{array}$ & $\begin{array}{c}0.12 \\
(0.16,1.00)\end{array}$ & $\begin{array}{c}-0.01 \\
(0.12,1.00)\end{array}$ & $\begin{array}{c}-0.01 \\
(0.13,1.00)\end{array}$ & $\begin{array}{c}-0.00 \\
(0.35,1.00)\end{array}$ & $\begin{array}{c}0.06 \\
(0.32,1.00)\end{array}$ & $\begin{array}{c}0.01 \\
(0.69,1.00)\end{array}$ \\
\hline
\end{tabular}

Note: p-values in brackets. On the left, the standard p-values and, on the right, those with the Bonferroni correction. The average number of observations is 120 , oscillating between a minimum of 91 and a maximum of 259 . 
Table 2: Effect of external position (CA/GDP) on characteristics of recoveries; with control variables

\begin{tabular}{|c|c|c|c|c|c|c|c|c|c|c|c|c|c|c|c|}
\hline Endogeno & CA1 & CA2 & CA3 & CA4 & CA5 & CA6 & CA7 & CA8 & CA9 & CA10 & CA11 & CA12 & CA13 & CA14 & CA15 \\
\hline Duration & 0.07 & 0.00 & -0.01 & -0.03 & -0.43 & -0.15 & -1.92 & 1.04 & 3.91 & & -0.00 & & & 2.10 & 0.01 \\
\hline & & $99,1.00)$ & $0.96,1.00)$ & $(0.88,1.00)$ & $(0.09,1.0 c$ & $(0.55,1.00)$ & $(0.18,1.00)$ & $(0.29,1.00)$ & $.28,1.00)$ & $0.73,1.00)$ & $(1.00,1.0$ & $(0.92,1.0$ & $.60,1.0$ & $.53,1.00)$ & $1.99,1.00)$ \\
\hline Amplitude & $(0.27,1.00)$ & $\begin{array}{c}-0.00 \\
(0.19,1.00)\end{array}$ & $\begin{array}{c}-0.00 \\
(0.15,1.00)\end{array}$ & $\begin{array}{c}-0.00 \\
(0.10,1.00)\end{array}$ & $\begin{array}{c}-0.01 \\
(0.02,0.28)\end{array}$ & $\begin{array}{c}-0.00 \\
(0.08,1.00)\end{array}$ & $\begin{array}{c}-0.02 \\
(0.10,1.00)\end{array}$ & $\begin{array}{c}0.02 \\
(0.12,1.00)\end{array}$ & $\begin{array}{c}0.05 \\
(0.13,1.00)\end{array}$ & $\begin{array}{c}0.00 \\
(0.90,1.00)\end{array}$ & $\begin{array}{c}-0.00 \\
(0.20,1.00)\end{array}$ & $\begin{array}{c}-0.01 \\
(0.22,1.00)\end{array}$ & $\begin{array}{c}-0.00 \\
(0.11,1.00)\end{array}$ & $\begin{array}{c}-0.05 \\
(0.28,1.00)\end{array}$ & $\begin{array}{c}-0.00 \\
(0.76,1.00)\end{array}$ \\
\hline Cumulation & $\begin{array}{c}-0.07 \\
(0.46,1.00)\end{array}$ & $\begin{array}{c}-0.08 \\
(0.34,1.00)\end{array}$ & $\begin{array}{c}-0.08 \\
(0.30,1.00)\end{array}$ & $\begin{array}{c}-0.08 \\
(0.26,1.00)\end{array}$ & $\begin{array}{c}-0.24 \\
(0.02,0.25)\end{array}$ & $\begin{array}{c}-0.12 \\
(0.21,1.00)\end{array}$ & $\begin{array}{l}-1.14 \\
.04,0.60)\end{array}$ & $\begin{array}{l}0.54 \\
.34,1.00)\end{array}$ & $\begin{array}{c}1.15 \\
0.49,1.00)\end{array}$ & $\begin{array}{c}0.31 \\
(0.87,1.00)\end{array}$ & $\begin{array}{c}-0.09 \\
(0.46,1.00)\end{array}$ & $\begin{array}{c}-0.26 \\
(0.25,1.00)\end{array}$ & $\begin{array}{l}-0.08 \\
.42,1.00)\end{array}$ & $\begin{array}{l}-3.14 \\
.10,1.00)\end{array}$ & $\begin{array}{c}0.15 \\
0.71,1.00)\end{array}$ \\
\hline Excess & $\begin{array}{c}-0.00 \\
(0.92,1.00)\end{array}$ & $\begin{array}{c}-0.01 \\
(0.64,1.00)\end{array}$ & $\begin{array}{c}-0.01 \\
(0.59,1.00)\end{array}$ & $\begin{array}{c}-0.01 \\
(0.59,1.00)\end{array}$ & $\begin{array}{c}0.01 \\
(0.74,1.00)\end{array}$ & $\begin{array}{c}-0.02 \\
(0.29,1.00)\end{array}$ & $\begin{array}{c}-0.11 \\
(0.31,1.00)\end{array}$ & $\begin{array}{c}0.10 \\
(0.15,1.00)\end{array}$ & $\begin{array}{c}-0.03 \\
(0.82,1.00)\end{array}$ & $\begin{array}{c}-0.14 \\
(0.48,1.00)\end{array}$ & $\begin{array}{c}0.01 \\
(0.49,1.00)\end{array}$ & $\begin{array}{c}0.01 \\
(0.60,1.00)\end{array}$ & $\begin{array}{c}0.04 \\
(0.06,0.93)\end{array}$ & $\begin{array}{c}0.09 \\
(0.77,1.00)\end{array}$ & $\begin{array}{c}0.02 \\
(0.76,1.00)\end{array}$ \\
\hline Early shape & $\begin{array}{c}0.02 \\
(0.36,1.00)\end{array}$ & $\begin{array}{c}0.01 \\
(0.39,1.00)\end{array}$ & $\begin{array}{c}0.01 \\
(0.41,1.00)\end{array}$ & $\begin{array}{c}0.01 \\
(0.38,1.00)\end{array}$ & $\begin{array}{c}0.01 \\
(0.44,1.00)\end{array}$ & $\begin{array}{c}0.02 \\
(0.16,1.00)\end{array}$ & $\begin{array}{c}0.15 \\
(0.06,0.93)\end{array}$ & $\begin{array}{c}-0.09 \\
(0.20,1.00)\end{array}$ & $\begin{array}{c}0.12 \\
0.46,1.00)\end{array}$ & $\begin{array}{c}0.03 \\
(0.86,0.93)\end{array}$ & $\begin{array}{c}0.02 \\
(0.27,1.00)\end{array}$ & $\begin{array}{c}0.02 \\
(0.41,1.00)\end{array}$ & $\begin{array}{c}0.02 \\
(0.11,1.00)\end{array}$ & $\begin{array}{l}-0.25 \\
0.14,1.00)\end{array}$ & $\begin{array}{c}-0.05 \\
0.26,1.00)\end{array}$ \\
\hline Insha & $\begin{array}{c}0.21 \\
(0.37,1.00)\end{array}$ & $\begin{array}{l}0.17 \\
.43,1.00)\end{array}$ & $\begin{array}{c}0.17 \\
(0.37,1.00)\end{array}$ & $\begin{array}{c}0.18 \\
(0.30,1.00)\end{array}$ & $\begin{array}{c}0.32 \\
(0.17,1.00)\end{array}$ & $\begin{array}{c}0.10 \\
(0.68,1.00)\end{array}$ & $\begin{array}{c}2.38 \\
(0.15,1.00)\end{array}$ & $\begin{array}{c}-0.66 \\
(0.72,1.00)\end{array}$ & $\begin{array}{c}-0.61 \\
0.85,1.00)\end{array}$ & $\begin{array}{c}-3.24 \\
(0.28,1.00)\end{array}$ & $\begin{array}{c}0.40 \\
(0.19,1.00)\end{array}$ & $\begin{array}{c}0.40 \\
(0.18,1.00)\end{array}$ & $\begin{array}{c}0.54 \\
(0.10,1.00)\end{array}$ & $\begin{array}{c}2.70 \\
0.40,1.00)\end{array}$ & $\begin{array}{c}-0.00 \\
(1.00,1.00)\end{array}$ \\
\hline Half life & $\begin{array}{c}0.00 \\
(0.83,1.00)\end{array}$ & $\begin{array}{c}0.00 \\
(0.67,1.00)\end{array}$ & $\begin{array}{r}0.0 \\
(0.75,1\end{array}$ & $\begin{array}{r}0.0 \\
(0.87,1\end{array}$ & $\begin{array}{c}-0.00 \\
(0.44,1.00)\end{array}$ & $\begin{array}{r}-0 . \\
(0.64,\end{array}$ & $\begin{array}{r}-0.0 \\
(0.86,\end{array}$ & $\begin{array}{c}0.01 \\
(0.33,1.00)\end{array}$ & $\begin{array}{c}0.04 \\
(0.10,1.00)\end{array}$ & $\begin{array}{r}0.0 \\
(0.76,1\end{array}$ & $\begin{array}{r}0.6 \\
(0.31,\end{array}$ & & $\begin{array}{c}0.00 \\
(0.46,1.00)\end{array}$ & $\begin{array}{c}0.02 \\
(0.36,1.00)\end{array}$ & $\begin{array}{c}0.01 \\
(0.22,1.00)\end{array}$ \\
\hline Medium ar & $\begin{array}{c}0.01 \\
(0.26,1.00)\end{array}$ & $\begin{array}{c}0.01 \\
(0.36,1.00)\end{array}$ & $\begin{array}{c}-0.00 \\
(0.67,1.00)\end{array}$ & $\begin{array}{c}-0.01 \\
(0.57,1.00)\end{array}$ & $\begin{array}{c}-0.00 \\
(0.82,1.00)\end{array}$ & $\begin{array}{c}0.01 \\
(0.34,1.00)\end{array}$ & $\begin{array}{c}0.07 \\
(0.11,1.00)\end{array}$ & $\begin{array}{c}-0.00 \\
(0.93,1.00)\end{array}$ & $\begin{array}{c}-0.07 \\
(0.62,1.00)\end{array}$ & $\begin{array}{c}-0.04 \\
(0.65,1.00)\end{array}$ & $\begin{array}{c}0.01 \\
(0.31,1.00)\end{array}$ & $\begin{array}{c}0.01 \\
(0.24,1.00)\end{array}$ & $\begin{array}{c}0.01 \\
(0.31,1.00)\end{array}$ & $\begin{array}{c}-0.13 \\
(0.09,1.00)\end{array}$ & $\begin{array}{c}-0.05 \\
(0.07,0.99)\end{array}$ \\
\hline Time $\mathrm{t}$ & $\begin{array}{c}-\mathbf{0 . 0 1} \\
(0.00,0.05)\end{array}$ & $\begin{array}{c}-\mathbf{0 . 0 1} \\
(0.00,0.03)\end{array}$ & $\begin{array}{c}-0.01 \\
(0.00,0.02)\end{array}$ & $\begin{array}{c}-0.01 \\
(0.00,0.05)\end{array}$ & $\begin{array}{c}-0.01 \\
(0.19,1.00)\end{array}$ & $\begin{array}{c}-0.01 \\
(0.01,0.06)\end{array}$ & $\begin{array}{c}-0.05 \\
(0.12,0.92)\end{array}$ & $\begin{array}{c}-0.00 \\
(0.93,1.00)\end{array}$ & $\begin{array}{c}-0.12 \\
(0.11,0.96)\end{array}$ & $\begin{array}{c}-0.05 \\
(0.46,1.00)\end{array}$ & $\begin{array}{c}-0.01 \\
(0.11,0.96)\end{array}$ & $\begin{array}{c}-0.01 \\
(0.02,0.25)\end{array}$ & $\begin{array}{c}-0.00 \\
(0.24,1.00)\end{array}$ & $\begin{array}{c}-0.01 \\
(0.87,1.00)\end{array}$ & $\begin{array}{c}-0.01 \\
(0.54,1.00)\end{array}$ \\
\hline
\end{tabular}

Note: p-values in brackets. On the left, the standard p-values and, on the right, those with the Bonferroni correction. We introduce the following control variables: geography, income, trade openness, exchange rate regime, financial development, financial openness, oil price and labour market regulation. We have applied a general-to-specific method to select the most suitable set of control variables in each specification. The average number of observations is 108 , oscillating between a minimum of 77 and a maximum of 259. 
Table 3: Effect of external position (CA/GDP) on characteristics of recoveries; with control variables

\begin{tabular}{|c|c|c|c|c|c|c|c|c|c|c|c|c|c|c|c|}
\hline Endogenous/Exogenous & CA1 & $\overline{C \text { CA2 }}$ & CA3 & CA4 & CA5 & CA6 & CA7 & CA8 & CA9 & CA10 & CA11 & CA12 & CA13 & CA14 & CA15 \\
\hline Duration & 0.5 & 0.68 & 0.23 & 0.16 & -1.28 & -0.44 & -1.7 & -0.8 & -3.41 & & 1.07 & 2.43 & 0.59 & 1.71 & -2.24 \\
\hline & $.66,1.00)$ & $.52,1.00)$ & $84,1.00)$ & $0.90,1.00)$ & .21,1.00) & 0) & $.25,1.00)$ & $.66,1.00)$ & $.29,1.00)$ & 00) & $0.54,1.00)$ & $(0.20$ & $(0.6$ & & $0.00,0.03)$ \\
\hline Amplitude & 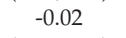 & -0.02 & -0.02 & -0.02 & -0.04 & -0.0 & -0.0 & -0.0 & 0.01 & 0.0 & 0.8 & -0 . & & & \\
\hline & )) & $0.30,1.00)$ & 0.301 .0 & $0.27,1.0$ & $0.01,0.10)$ & $.17,1.00)$ & $.06,0.77)$ & $82,1.00)$ & $79,1.00)$ & $62,1.00)$ & 0) & $(0.31$, & & & $.00,0.00)$ \\
\hline Cumulation & $(0.30,1$ & $(0.5$ & $(0.59,1$ & $(0.42$ & $\begin{array}{r}-1 \\
(0.03\end{array}$ & 0) & $(0.06$ & $00)$ & 00) & 00) & $\begin{array}{c}1.11 \\
(0.20,1.00)\end{array}$ & $\begin{array}{r}-0 . \\
(0.84,\end{array}$ & & 0) & $\begin{array}{c}-0.59 \\
0.02,0.27)\end{array}$ \\
\hline Excess & $\begin{array}{c}0.01 \\
(0.82,1.00)\end{array}$ & $\begin{array}{l}0.02 \\
.75,1.00)\end{array}$ & $\begin{array}{l}0.02 \\
.74,1.0\end{array}$ & $\begin{array}{r}0.0 \\
(0.79 .1\end{array}$ & $\begin{array}{r}0 . \\
(0.02\end{array}$ & 0 & $\begin{array}{r}-0 . \\
(0.11\end{array}$ & $\begin{array}{l}-0 . \\
0.37\end{array}$ & $\begin{array}{c}-0.03 \\
0.85,1.00)\end{array}$ & $\begin{array}{c}-0.05 \\
(0.77,1.00)\end{array}$ & $\begin{array}{c}0.02 \\
(0.79,1.00)\end{array}$ & & & & $\begin{array}{c}0.02 \\
0.43,1.00)\end{array}$ \\
\hline Ea & $\begin{array}{c}0.00 \\
(0.98,1.00)\end{array}$ & $\begin{array}{l}-0.00 \\
.93,1.00)\end{array}$ & $\begin{array}{r}0.0 \\
.48,1\end{array}$ & $\begin{array}{c}0.03 \\
(0.53,1.00)\end{array}$ & $\begin{array}{c}0.05 \\
(0.27,1.00)\end{array}$ & 0.02 & $\begin{array}{c}0.09 \\
0.18,1.00)\end{array}$ & 0.07 & 0) & $\begin{array}{r}-0 . \\
(0.95,\end{array}$ & $\begin{array}{c}-0.07 \\
(0.26,1.00)\end{array}$ & $\begin{array}{c}0.01 \\
(0.84,1.00)\end{array}$ & -0 & $00)$ & $\begin{array}{c}0.01 \\
0.92,1.00)\end{array}$ \\
\hline hat & 0.37 & $\begin{array}{l}0.46 \\
.48,1.0\end{array}$ & 0.86 & $\begin{array}{r}0.4 \\
(0.54 .1\end{array}$ & $\begin{array}{c}1.37 \\
0.07 .1 .00\end{array}$ & 0.73 & $\begin{array}{c}-1.64 \\
(0.241 .00)\end{array}$ & 0.08 & $\begin{array}{l}-0.31 \\
0.88,1.00)\end{array}$ & $\begin{array}{c}-1.72 \\
(0.44 .1 .00)\end{array}$ & $\begin{array}{c}0.07 \\
(0.951 .00)\end{array}$ & $\begin{array}{c}1.46 \\
(0.23 .1 .00)\end{array}$ & $\begin{array}{c}0.21 \\
(0.79,1.0\end{array}$ & 1.61 & $\begin{array}{c}0.97 \\
0.21 .1 .00)\end{array}$ \\
\hline Half & $\begin{array}{c}0.01 \\
(0.39,1.00)\end{array}$ & $\begin{array}{l}0.01 \\
.41,1.00)\end{array}$ & $\begin{array}{c}0.01 \\
(0.49,1.00)\end{array}$ & $\begin{array}{c}0.01 \\
(0.44,1.00)\end{array}$ & $\begin{array}{c}0.00 \\
(0.97,1.00)\end{array}$ & $\begin{array}{c}0.00 \\
(0.96,1.00)\end{array}$ & $\begin{array}{r}-0.0 \\
(0.13,1\end{array}$ & $\begin{array}{r}-0 . \\
0.79\end{array}$ & $\begin{array}{c}-0.03 \\
0.09,1.00)\end{array}$ & $\begin{array}{c}-0.04 \\
(0.09,1.00)\end{array}$ & $\begin{array}{c}-0.01 \\
(0.61,1.00)\end{array}$ & $\begin{array}{c}0.02 \\
(0.23,1.00)\end{array}$ & $\begin{array}{c}0.01 \\
(0.41,1.00)\end{array}$ & $\begin{array}{c}0.01 \\
(0.32,1.00)\end{array}$ & $\begin{array}{c}-0.01 \\
(0.20,1.00)\end{array}$ \\
\hline Mediun & $\begin{array}{c}-0.06 \\
(0.58,1.00)\end{array}$ & $\begin{array}{c}-0.04 \\
(0.65,1.00)\end{array}$ & $\begin{array}{c}-0.05 \\
(0.64,1.00\end{array}$ & $\begin{array}{c}-0.06 \\
(0.62,1.00\end{array}$ & $\begin{array}{c}-0.04 \\
(0.58,1.00)\end{array}$ & $\begin{array}{c}-0.09 \\
(0.57,1.0\end{array}$ & $\begin{array}{r}-0.0 \\
(0.82,1\end{array}$ & $\begin{array}{r}0.0 \\
(0.44,1\end{array}$ & $\begin{array}{c}0.17 \\
(0.21,1.0\end{array}$ & $\begin{array}{c}0.24 \\
(0.16,1.00)\end{array}$ & $\begin{array}{c}0.14 \\
(0.34,1.00)\end{array}$ & $\begin{array}{c}-0.09 \\
(0.53,1.00)\end{array}$ & $\begin{array}{c}-0.09 \\
(0.52,1.00)\end{array}$ & & $\begin{array}{c}0.00 \\
(0.85,1.00)\end{array}$ \\
\hline Time ts & $\begin{array}{c}-0.08 \\
(0.02,0.21)\end{array}$ & $\begin{array}{c}-0.07 \\
(0.11,0.78)\end{array}$ & $\begin{array}{c}-0.07 \\
(0.15,0.88)\end{array}$ & $\begin{array}{c}-0.07 \\
(0.19,0.97)\end{array}$ & $\begin{array}{c}-0.03 \\
(0.38,1.00)\end{array}$ & $\begin{array}{c}-0.05 \\
(0.44,1.00)\end{array}$ & $\begin{array}{c}-0.01 \\
(0.74,1.00)\end{array}$ & $\begin{array}{c}0.02 \\
(0.56,1.00)\end{array}$ & $\begin{array}{c}\mathbf{0 . 2 1} \\
(0.00,0.00)\end{array}$ & $\begin{array}{c}0.15 \\
(0.01,0.12)\end{array}$ & $\begin{array}{c}0.08 \\
(0.02,0.21)\end{array}$ & $\begin{array}{c}-0.10 \\
(0.00,0.03)\end{array}$ & $\begin{array}{c}-0.09 \\
(0.08,0.61)\end{array}$ & $\begin{array}{c}-0.06 \\
(0.03,0.25)\end{array}$ & $\begin{array}{c}0.05 \\
(0.00,0.06)\end{array}$ \\
\hline
\end{tabular}

Note: p-values in brackets. On the left, the standard p-values and, on the right, those with the Bonferroni correction. We introduce the following control variables: geography, income, trade openness, exchange rate regime, financial development, financial openness, oil price and labour market regulation. The set of control variables has been selected by maximizing the number of significant variables after the Bonferroni correction. The average number of observations is 108, oscillating between a minimum of 77 and a maximum of 259 . 
Table 4: Effect of external position (NFA/GDP) on characteristics of recoveries

\begin{tabular}{|c|c|c|c|c|c|c|c|c|c|c|c|c|c|c|c|}
\hline Endogenous/Exogenous & $\overline{\text { NFA1 }}$ & $\overline{\mathrm{NFA2}}$ & $\overline{\mathrm{NFA3}}$ & $\overline{\text { NFA4 }}$ & $\overline{\text { NFA5 }}$ & $\overline{\text { NFA6 }}$ & $\overline{\text { NFA7 }}$ & $\overline{\text { NFA8 }}$ & $\overline{\text { NFA9 }}$ & $\overline{N F A 10}$ & NFA11 & NFA12 & NFA13 & NFA14 & NFA15 \\
\hline Duration & 1.26 & 1.26 & 1.28 & 1.24 & -1.08 & 0.30 & -2.24 & -1.50 & -3.13 & -2.26 & & 3.89 & 1.73 & 3.25 & -2.89 \\
\hline & $(0.32,1.00)$ & $(0.28,1.00)$ & $(0.28,1.00)$ & $(0.35,1.00)$ & $(0.29,1.00)$ & $(0.86,1.00)$ & $(0.16,1.00)$ & $(0.43,1.00)$ & $.35,1.00)$ & $0.60,1.00)$ & $(0.86,1.00)$ & $(0.05,0.74)$ & $(0.24,1.00)$ & $(0.11,1.00)$ & $(0.00,0.00)$ \\
\hline Amplitude & -0.01 & -0.01 & -0.0 & -0.01 & -0.04 & -0. & -0.05 & -0.0 & 0.0 & 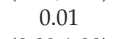 & 0 & 0.8 & & & \\
\hline & $(0.51,1.00)$ & $(0.56$ & $(0.58,1.00)$ & $(0.52,1.00)$ & $(0.01,0.14)$ & $(0.18,1.00)$ & $(0.01,0.16)$ & $(0.51,1.00)$ & $(0.73,1.00)$ & $(0.89,1.00)$ & $(0.30,1.00)$ & $(0.54,1.00)$ & $(0.53$ & & $(0.00$ \\
\hline Cumulation & $\begin{array}{c}-0.45 \\
(0.51,1.00)\end{array}$ & $\begin{array}{c}-0.35 \\
(0.58,1.00)\end{array}$ & $\begin{array}{c}-0.28 \\
(0.64,1.00)\end{array}$ & $\begin{array}{c}-0.32 \\
(0.62,1.00)\end{array}$ & $\begin{array}{c}-1.03 \\
(0.03,0.43)\end{array}$ & $\begin{array}{c}-0.74 \\
(0.33,1.00)\end{array}$ & $\begin{array}{c}-1.28 \\
(0.04,0.55)\end{array}$ & $\begin{array}{c}-0.53 \\
(0.42,1.00)\end{array}$ & $\begin{array}{c}0.54 \\
(0.74,1.00)\end{array}$ & $\begin{array}{c}0.98 \\
(0.66,1.00)\end{array}$ & $\begin{array}{c}1.01 \\
(0.24,1.00)\end{array}$ & $\begin{array}{c}1.30 \\
(0.26,1.00)\end{array}$ & $\begin{array}{c}-0.39 \\
(0.56,1.00)\end{array}$ & $\begin{array}{c}1.33 \\
(0.32,1.00)\end{array}$ & $\begin{array}{c}-0.80 \\
0.00,0.00)\end{array}$ \\
\hline Excess & $\begin{array}{r}0.03 \\
(0.331 .1 .\end{array}$ & $\begin{array}{c}0.03 \\
31.1\end{array}$ & $\begin{array}{r}0.03 \\
(0.351 .1 .\end{array}$ & $\begin{array}{r}0.03 \\
0.41 .1 .0\end{array}$ & 0.1 & 0.0 & -0. & $\begin{array}{l}-0.09 \\
0.3910\end{array}$ & $\begin{array}{r}-0.02 \\
(0.851 .0\end{array}$ & $\begin{array}{l}-0.0 \\
0.77 .1\end{array}$ & -0.03 & 0.11 & 0.1 & 0.16 & $\begin{array}{c}0.02 \\
(0.46,1.00)\end{array}$ \\
\hline Early shape & $\begin{array}{c}0.03 \\
(0.68,1.00)\end{array}$ & $\begin{array}{c}0.02 \\
(0.69,1.00)\end{array}$ & $\begin{array}{c}0.02 \\
(0.72,1.00)\end{array}$ & $\begin{array}{c}0.02 \\
(0.71,1.00)\end{array}$ & $\begin{array}{c}0.08 \\
(0.14,1.00)\end{array}$ & $\begin{array}{c}0.08 \\
(0.38,1.00)\end{array}$ & $\begin{array}{c}0.10 \\
(0.09,1.00)\end{array}$ & $\begin{array}{c}0.13 \\
(0.10,1.00)\end{array}$ & $\begin{array}{c}0.03 \\
(0.77,1.00)\end{array}$ & $\begin{array}{c}-0.01 \\
(0.93,1.00)\end{array}$ & $\begin{array}{c}-0.07 \\
(0.25,1.00)\end{array}$ & $\begin{array}{c}0.03 \\
(0.68,1.00)\end{array}$ & $\begin{array}{c}0.01 \\
(0.87,1.00)\end{array}$ & $\begin{array}{c}0.03 \\
(0.68,1.00)\end{array}$ & $\begin{array}{c}0.06 \\
(0.12,1.00)\end{array}$ \\
\hline Insha & $\begin{array}{c}0.35 \\
(0.65,1.00)\end{array}$ & $\begin{array}{c}0.42 \\
(0.59,1.00)\end{array}$ & $\begin{array}{c}0.37 \\
(0.63,1.00)\end{array}$ & $\begin{array}{c}0.34 \\
(0.68,1.00)\end{array}$ & $\begin{array}{c}1.50 \\
(0.11,1.00)\end{array}$ & $\begin{array}{c}0.63 \\
(0.50,1.00)\end{array}$ & $\begin{array}{c}-0.35 \\
(0.75,1.00)\end{array}$ & $\begin{array}{c}0.79 \\
(0.66,1.00)\end{array}$ & $\begin{array}{c}0.75 \\
(0.66,1.00)\end{array}$ & $\begin{array}{c}-0.75 \\
(0.69,1.00)\end{array}$ & $\begin{array}{c}0.03 \\
(0.97,1.00)\end{array}$ & $\begin{array}{c}0.51 \\
(0.68,1.00)\end{array}$ & $\begin{array}{c}0.22 \\
(0.80,1.00)\end{array}$ & $\begin{array}{c}0.83 \\
(0.53,1.00)\end{array}$ & $\begin{array}{c}0.97 \\
(0.21,1.00)\end{array}$ \\
\hline Half life & $\begin{array}{c}0.01 \\
(0.17,1.00)\end{array}$ & $\begin{array}{c}0.01 \\
(0.19,1.00)\end{array}$ & $\begin{array}{c}0.01 \\
(0.26,1.00)\end{array}$ & $\begin{array}{c}0.01 \\
(0.37,1.00)\end{array}$ & $\begin{array}{c}0.00 \\
(0.82,1.00)\end{array}$ & $\begin{array}{c}-0.00 \\
(0.94,1.00)\end{array}$ & $\begin{array}{c}-0.02 \\
(0.10,1.00)\end{array}$ & $\begin{array}{c}-0.02 \\
(0.22,1.00)\end{array}$ & $\begin{array}{c}-0.03 \\
(0.10,1.00)\end{array}$ & $\begin{array}{c}-0.04 \\
(0.10,1.00)\end{array}$ & $\begin{array}{c}-0.01 \\
(0.48,1.00)\end{array}$ & $\begin{array}{c}0.02 \\
(0.07,0.96)\end{array}$ & $\begin{array}{c}0.02 \\
(0.13,1.00)\end{array}$ & $\begin{array}{c}0.02 \\
(0.09,1.00)\end{array}$ & $\begin{array}{c}-0.01 \\
(0.02,0.37)\end{array}$ \\
\hline Medium & $\begin{array}{c}-0.04 \\
(0.61,1.00)\end{array}$ & $\begin{array}{c}-0.04 \\
(0.61,1.00)\end{array}$ & $\begin{array}{c}-0.05 \\
(0.58,1.00)\end{array}$ & $\begin{array}{c}-0.06 \\
(0.57,1.00)\end{array}$ & $\begin{array}{c}-0.03 \\
(0.67,1.00)\end{array}$ & $\begin{array}{c}-0.08 \\
(0.58,1.00)\end{array}$ & $\begin{array}{c}0.02 \\
(0.65,1.00)\end{array}$ & $\begin{array}{c}0.09 \\
(0.11,1.00)\end{array}$ & $\begin{array}{c}0.11 \\
(0.32,1.00)\end{array}$ & $\begin{array}{c}0.18 \\
(0.22,1.00)\end{array}$ & $\begin{array}{c}0.10 \\
(0.37,1.00)\end{array}$ & $\begin{array}{c}-0.07 \\
(0.51,1.00)\end{array}$ & $\begin{array}{c}-0.08 \\
(0.48,1.00)\end{array}$ & $\begin{array}{c}0.02 \\
(0.39,1.00)\end{array}$ & $\begin{array}{c}0.02 \\
(0.26,1.00)\end{array}$ \\
\hline Time to recovery & $\begin{array}{c}-0.09 \\
(0.03,0.26)\end{array}$ & $\begin{array}{c}-0.08 \\
(0.04,0.30)\end{array}$ & $\begin{array}{c}-0.08 \\
(0.07,0.42)\end{array}$ & $\begin{array}{c}-0.08 \\
(0.11,0.57)\end{array}$ & $\begin{array}{c}-0.04 \\
(0.24,0.97)\end{array}$ & $\begin{array}{c}-0.05 \\
(0.44,1.00)\end{array}$ & $\begin{array}{c}0.00 \\
(0.94,1.00)\end{array}$ & $\begin{array}{c}0.02 \\
(0.58,1.00)\end{array}$ & $\begin{array}{c}0.17 \\
(0.00,0.01)\end{array}$ & $\begin{array}{c}0.19 \\
(0.00,0.04)\end{array}$ & $\begin{array}{c}0.09 \\
(0.02,0.19)\end{array}$ & $\begin{array}{c}-0.12 \\
(0.00,0.04)\end{array}$ & $\begin{array}{c}-0.10 \\
(0.03,0.26)\end{array}$ & $\begin{array}{c}-0.09 \\
(0.00,0.03)\end{array}$ & $\begin{array}{c}\mathbf{0 . 0 6} \\
(0.00,0.01)\end{array}$ \\
\hline
\end{tabular}

Note: p-values in brackets. On the left, the standard p-values and, on the right, those with the Bonferroni correction. The average number of observations is 207, oscillating between a minimum of 183 and a maximum of 231 . 
Table 5: Effect of external position (NFA/GDP) on characteristics of recoveries; with control variables

\begin{tabular}{|c|c|c|c|c|c|c|c|c|c|c|c|c|c|c|c|}
\hline kogenous & NF1 & NFA2 & NFA3 & NFA4 & NFA5 & $\overline{~ N F A 6 ~}$ & $\begin{array}{l}\text { NFA7 } \\
\end{array}$ & NFA8 & NFA9 & NFA10 & NFA11 & NFA12 & NFA13 & NFA14 & NFA15 \\
\hline Duration & 0.47 & 0.53 & 0.57 & 0.56 & -1.21 & -0.24 & -2.26 & -1. & -3 . & -2.57 & 0.67 & 2.54 & 1.01 & 2.29 & -1.62 \\
\hline & $(0.70,1.00)$ & $.63,1.00)$ & $0.61,1.00)$ & $0.66,1.00)$ & $.23,1.00)$ & .89, & $.14,1.00)$ & $.56,1.00)$ & 00) & $(0.53,1.00)$ & $(0.68$ & & $(0.44,1.00)$ & 0)) & $.01,0.22)$ \\
\hline Amplitude & $\begin{array}{c}-0.02 \\
(0.27 .1 .00)\end{array}$ & $\begin{array}{c}-0.02 \\
(0.301 .00)\end{array}$ & $\begin{array}{c}-0.02 \\
(0.321 .00)\end{array}$ & $\begin{array}{c}-0.02 \\
(0.301 .00)\end{array}$ & $\begin{array}{c}-\mathbf{0 . 0 4} \\
(0.01,0.10)\end{array}$ & $\begin{array}{l}-0.03 \\
171.00)\end{array}$ & $\begin{array}{l}-0.03 \\
05.0 .71)\end{array}$ & $\begin{array}{l}-0.01 \\
601.00)\end{array}$ & $\begin{array}{c}0.01 \\
0.87 .00)\end{array}$ & $\begin{array}{c}0.01 \\
(0.80 .1 .00)\end{array}$ & $\begin{array}{c}0.03 \\
(0.241 .00\end{array}$ & $\begin{array}{l}-0.00 \\
.94 .1 .00)\end{array}$ & $\begin{array}{l}-0.02 \\
.29 .1 .00)\end{array}$ & $\begin{array}{l}-0.00 \\
94.1 .00)\end{array}$ & $\begin{array}{l}-\mathbf{- 0 . 0 2} \\
00,0.00)\end{array}$ \\
\hline Cumulation & & & & & & & & & & & & & & & \\
\hline & ${ }^{29}{ }^{2}$ & $(0.34$, & 0.35 & & 0.02 & & & & & & & & & & \\
\hline Excess & $\begin{array}{l}0.01 \\
.82,1.00)\end{array}$ & $\begin{array}{l}0.02 \\
.75,1.00)\end{array}$ & $\begin{array}{r}0 . c \\
(0.74\end{array}$ & $\begin{array}{r}0.6 \\
(0.79\end{array}$ & $\begin{array}{r}0 . \\
(0.02\end{array}$ & $\begin{array}{r}0 \\
(0.76\end{array}$ & $\begin{array}{r}-0 \\
0.09\end{array}$ & $\begin{array}{r}-0 \\
.33\end{array}$ & $\begin{array}{r}-0 \\
0.66\end{array}$ & $\begin{array}{r}-c \\
(0.72\end{array}$ & $\begin{array}{r}0 . \\
(0.79\end{array}$ & $\begin{array}{r}0 . \\
(0.29\end{array}$ & 0) & 00) & $\begin{array}{l}-0.04 \\
0.32,1.00)\end{array}$ \\
\hline Early shape & 0.03 & -0.00 & -0.6 & -0. & 0. & $0 . \mathrm{C}$ & 0.07 & 0. & 0. & -0 & -0. & 0. & 0. & $\begin{array}{c}-0.00 \\
(0.96,1.00)\end{array}$ & $\begin{array}{c}0.04 \\
(0.13,1.00)\end{array}$ \\
\hline Inshape & 0 & 0.7 & 0. & 0. & $\begin{array}{r}1.3 \\
0.07\end{array}$ & 0.79 & -1.7 & 0.1 & $\begin{array}{r}-0 . \\
0.85\end{array}$ & $\begin{array}{l}-1 . \\
0.4\end{array}$ & $\begin{array}{c}0.29 \\
0.8110\end{array}$ & 0. & 0.46 & 0.81 & $\begin{array}{l}-0.24 \\
0.691 .00)\end{array}$ \\
\hline $\mathrm{H}$ & $\begin{array}{c}0.00 \\
(0.57,1.00)\end{array}$ & $\begin{array}{c}0.00 \\
(0.65,1.00)\end{array}$ & $\begin{array}{c}0.00 \\
(0.81,1.00)\end{array}$ & $\begin{array}{r}0 . \\
(0.99\end{array}$ & $\begin{array}{r}-0 . \\
(0.77,\end{array}$ & $\begin{array}{r}-0 . \\
(0.29\end{array}$ & $\begin{array}{r}-0 . \\
(0.12,\end{array}$ & $\begin{array}{l}-0 . \\
0.99\end{array}$ & $\begin{array}{l}-0 . \\
(0.10\end{array}$ & $\begin{array}{r}-0 \\
(0.01\end{array}$ & $\begin{array}{c}0.00 \\
(0.88,1.00)\end{array}$ & $\begin{array}{c}0.01 \\
(0.40,1.00)\end{array}$ & $\begin{array}{c}0.01 \\
(0.46,1.00)\end{array}$ & $\begin{array}{c}0.01 \\
(0.15,1.00)\end{array}$ & $\begin{array}{c}-0.00 \\
(0.52,1.00)\end{array}$ \\
\hline Medium area & -0.03 & $\begin{array}{c}-0.03 \\
(0.73,1.00)\end{array}$ & $\begin{array}{c}-0.05 \\
(0.63,1.00\end{array}$ & $\begin{array}{c}-0.05 \\
(0.66,1.00\end{array}$ & $\begin{array}{c}-0.02 \\
(0.75,1.00)\end{array}$ & & $\begin{array}{c}0.01 \\
(0.81,1.00\end{array}$ & $\begin{array}{c}0.09 \\
(0.13,1.00)\end{array}$ & $\begin{array}{c}0.11 \\
(0.32,1.00)\end{array}$ & $\begin{array}{c}0.17 \\
(0.21,1.00)\end{array}$ & $\begin{array}{c}0.13 \\
(0.33,1.00)\end{array}$ & $\begin{array}{c}-0.05 \\
(0.63,1.00)\end{array}$ & & $\begin{array}{c}0.02 \\
(0.55,1.00)\end{array}$ & $\begin{array}{c}0.01 \\
(0.57,1.00)\end{array}$ \\
\hline Time t & $\begin{array}{c}-0.07 \\
(0.10,0.77)\end{array}$ & $\begin{array}{c}-0.07 \\
(0.12,0.84)\end{array}$ & $\begin{array}{c}-0.07 \\
(0.16,0.94)\end{array}$ & $\begin{array}{c}-0.07 \\
(0.20,1.00)\end{array}$ & $\begin{array}{c}-0.03 \\
(0.43,1.00)\end{array}$ & $\begin{array}{c}-0.05 \\
(0.44,1.00)\end{array}$ & $\begin{array}{c}-0.01 \\
(0.68,0.88)\end{array}$ & $\begin{array}{c}0.02 \\
(0.41,1.00)\end{array}$ & $\begin{array}{c}\mathbf{0 . 1 8} \\
(0.00,0.00)\end{array}$ & $\begin{array}{c}\mathbf{0 . 1 8} \\
(0.00,0.01)\end{array}$ & $\begin{array}{c}0.08 \\
(0.02,0.27)\end{array}$ & $\begin{array}{c}-0.09 \\
(0.03,0.31)\end{array}$ & $\begin{array}{c}-0.09 \\
(0.08,0.72)\end{array}$ & $\begin{array}{c}-0.05 \\
(0.05,0.56)\end{array}$ & $\begin{array}{c}0.02 \\
(0.07,0.66)\end{array}$ \\
\hline
\end{tabular}

Note: p-values in brackets.On the left, the standard p-values and, on the right, those with the Bonferroni correction. We introduce the following control variables: geography, income, trade openness, exchange rate regime, financial development, financial openness, oil price and labor market regulation. We have applied a general-to-specific method to select the most suitable set of control variables in each specification. The average number of observations is 190, oscillating between a minimum of 135 and a maximum of 230. 
Table 6: Effect of external position (NFA/GDP) on characteristics of recoveries; with control variables

\begin{tabular}{|c|c|c|c|c|c|c|c|c|c|c|c|c|c|c|c|}
\hline Endogenou & $\overline{\mathrm{JF} 1}$ & NFA2 & NFA3 & NFA4 & NFA5 & NFA6 & NFA7 & NFA8 & NFA9 & NFA10 & NFA11 & NFA12 & NFA13 & NFA14 & $\begin{array}{l}\text { NFA15 } \\
\end{array}$ \\
\hline Duration & 1.19 & 1.19 & 1.21 & 1.14 & -0.80 & 0.09 & -2.4 & -1.2 & -3.10 & -2.22 & 0.45 & 3.8 & 1.65 & 3.14 & -1.93 \\
\hline & $.36,1.00)$ & $.32,1.00)$ & $.33,1.00)$ & 41, & $.44,1.00)$ & $.96,1.00)$ & 14 & 00) & $(0.36,1.00)$ & $(0.61,1.00)$ & $(0.80$ & $(0.0$ & 00) & 70) & $.01,0.08)$ \\
\hline Amplitude & $\begin{array}{l}-0.02 \\
.251 .00)\end{array}$ & $\begin{array}{c}-0.02 \\
(0.281 .00)\end{array}$ & $\begin{array}{c}-0.02 \\
(0.301 .00)\end{array}$ & $\begin{array}{c}-0.02 \\
(0.281 .00)\end{array}$ & $\begin{array}{l}-\mathbf{- 0 . 0 4} \\
00.03)\end{array}$ & $\begin{array}{l}-0.03 \\
181.00)\end{array}$ & $\begin{array}{l}-0.04 \\
02.0 .27)\end{array}$ & $\begin{array}{l}-0.01 \\
0.58,1.00)\end{array}$ & $\begin{array}{c}0.02 \\
(0.711 .00)\end{array}$ & $\begin{array}{c}0.01 \\
(0.871 .00)\end{array}$ & $\begin{array}{c}0.03 \\
(0.22 .1 .00)\end{array}$ & $\begin{array}{l}-0.00 \\
.94 .1 .00)\end{array}$ & $\begin{array}{l}-0.02 \\
.251 .00)\end{array}$ & $\begin{array}{l}-0.01 \\
70.1 .00)\end{array}$ & $\begin{array}{l}-0.02 \\
.00 .0 .00)\end{array}$ \\
\hline Cumulation & $\begin{array}{c}-0.68 \\
(0.29,1.00)\end{array}$ & $\begin{array}{c}-0.56 \\
(0.34,1.00)\end{array}$ & $\begin{array}{l}-0.48 \\
0.39,1.00)\end{array}$ & $\begin{array}{r}-0 . \\
(0.40\end{array}$ & -1. & -0 & $\begin{array}{l}-1 . \\
0.06\end{array}$ & -0 & 0.55 & $\begin{array}{c}1.00 \\
(0.64,1.00\end{array}$ & 1.13 & & & 0) & \\
\hline Excess & $\begin{array}{c}0.03 \\
(0.58,1.00)\end{array}$ & $\begin{array}{r}0.0 \\
(0.51,\end{array}$ & $\begin{array}{r}0.1 \\
0.53,\end{array}$ & $\begin{array}{r}0 . \\
(0.60\end{array}$ & $\begin{array}{r}0.1 \\
(0.00,\end{array}$ & .0. & -0 . & & $\begin{array}{r}-0 \\
(0.67\end{array}$ & $\begin{array}{c}-0.04 \\
(0.83,1.00)\end{array}$ & $\begin{array}{r}-0 . \\
(0.94\end{array}$ & & & 0) & $\begin{array}{l}-0.00 \\
0.90,1.00)\end{array}$ \\
\hline Ea & $\begin{array}{l}0.03 \\
.67,1.00\end{array}$ & 0.02 & $\begin{array}{c}0.02 \\
0.77,1.00)\end{array}$ & $\begin{array}{c}0.02 \\
(0.75,1.00)\end{array}$ & 0.07 & 0.07 & 0. & 0. & $\begin{array}{r}0.6 \\
(0.93,\end{array}$ & $\begin{array}{c}-0.04 \\
(0.78,1.00)\end{array}$ & $\begin{array}{c}-0.09 \\
(0.15,1.00)\end{array}$ & 0. & $\begin{array}{c}0.02 \\
(0.82,1.00)\end{array}$ & $\begin{array}{l}0.02 \\
72,1.00)\end{array}$ & $\begin{array}{l}0.03 \\
.29,1.00)\end{array}$ \\
\hline sha & $\begin{array}{c}0.61 \\
.59,1.0\end{array}$ & $\begin{array}{c}0.59 \\
.60,1.0\end{array}$ & $\begin{array}{r}0.5 \\
(0.65,1\end{array}$ & $\begin{array}{r}0.5 \\
(0.67,1\end{array}$ & 0.85 & 0.40 & 0.74 & $\begin{array}{c}1.51 \\
(0.45,1.0\end{array}$ & $\begin{array}{c}-0.57 \\
(0.73,1.00)\end{array}$ & $\begin{array}{c}-1.14 \\
(0.53,1.00\end{array}$ & $\begin{array}{r}-0 \\
(0.29\end{array}$ & $\begin{array}{c}0.99 \\
(0.54,1.0\end{array}$ & $\begin{array}{c}0.57 \\
(0.66,1.0\end{array}$ & 0.47 & $\begin{array}{c}0.35 \\
(0.65,1.00)\end{array}$ \\
\hline Half 1 & $\begin{array}{c}\mathbf{0 . 0 2} \\
(0.00,0.06)\end{array}$ & $\begin{array}{c}\mathbf{0 . 0 2} \\
(0.01,0.10)\end{array}$ & $\begin{array}{r}0.0 \\
(0.03,\end{array}$ & $\begin{array}{c}0.02 \\
(0.06,0.42)\end{array}$ & $\begin{array}{c}0.01 \\
(0.22,1.00)\end{array}$ & 0.6 & $\begin{array}{l}-0 . \\
.52,\end{array}$ & $\begin{array}{l}-0 \\
0.85\end{array}$ & $\begin{array}{c}-0.04 \\
(0.04,0.39)\end{array}$ & $\begin{array}{c}-0.05 \\
(0.04,0.39)\end{array}$ & $\begin{array}{r}-0 . \\
(0.11,\end{array}$ & $\begin{array}{c}\mathbf{0 . 0 3} \\
(0.00,0.03)\end{array}$ & $\begin{array}{c}\mathbf{0 . 0 3} \\
(0.01,0.06)\end{array}$ & $\begin{array}{c}\mathbf{0 . 0 3} \\
0.00,0.02)\end{array}$ & $\begin{array}{c}-0.00 \\
(0.90,1.00)\end{array}$ \\
\hline Medium & $\begin{array}{c}0.02 \\
(0.38,1.00)\end{array}$ & $\begin{array}{c}0.02 \\
(0.33,1.00)\end{array}$ & $\begin{array}{c}0.02 \\
(0.42,1.0\end{array}$ & $\begin{array}{r}0.02 \\
(0.43,1\end{array}$ & $\begin{array}{c}0.02 \\
(0.25,1.0\end{array}$ & $\begin{array}{c}0.04 \\
(0.17,1.0\end{array}$ & $\begin{array}{r}0.0 \\
(0.26,1\end{array}$ & $\begin{array}{r}0.0 \\
(0.52,\end{array}$ & $\begin{array}{r}0.0 \\
(0.71,\end{array}$ & $\begin{array}{c}0.04 \\
(0.52,1.06\end{array}$ & $\begin{array}{r}-0 \\
(0.60\end{array}$ & & $\begin{array}{r}0.0 \\
(0.57\end{array}$ & $\begin{array}{r}0 . \\
(0.49\end{array}$ & $\begin{array}{c}0.02 \\
(0.26,1.00)\end{array}$ \\
\hline ne t & $\begin{array}{c}-\mathbf{0 . 1 1} \\
(0.00,0.01)\end{array}$ & $\begin{array}{c}-0.10 \\
(0.00,0.03)\end{array}$ & $\begin{array}{c}-0.10 \\
(0.01,0.08)\end{array}$ & $\begin{array}{c}-0.10 \\
(0.03,0.18)\end{array}$ & $\begin{array}{c}-0.06 \\
(0.15,0.76)\end{array}$ & $\begin{array}{c}-0.08 \\
(0.27,1.00)\end{array}$ & $\begin{array}{c}-0.03 \\
(0.42,0.84)\end{array}$ & $\begin{array}{c}0.00 \\
(1.00,1.00)\end{array}$ & $\begin{array}{c}\mathbf{0 . 1 8} \\
(0.00,0.02)\end{array}$ & $\begin{array}{c}\mathbf{0 . 1 8} \\
(0.00,0.04)\end{array}$ & $\begin{array}{c}\mathbf{0 . 1 1} \\
(0.00,0.04)\end{array}$ & $\begin{array}{c}-\mathbf{0 . 1 3} \\
(0.00,0.00)\end{array}$ & $\begin{array}{c}-\mathbf{0 . 1 3} \\
(0.00,0.01)\end{array}$ & $\begin{array}{c}-\mathbf{0 . 1 1} \\
(0.00,0.03)\end{array}$ & $\begin{array}{c}0.02 \\
(0.26,1.00)\end{array}$ \\
\hline
\end{tabular}

Note: p-values in brackets.On the left, the standard p-values and, on the right, those with the Bonferroni correction. We introduce the following control variables: geography, income, trade openness, exchange rate regime, financial development, financial openness, oil price and labour market regulation. The set of control variables has been selected by maximizing the number of significant variables after the Bonferroni correction. The average number of observations is 190, oscillating between a minimum of 135 and a maximum of 230 . 


\section{Figures}

Figure 1: Chronology of business cycles (Bry-Boschan method) and CA/GDP

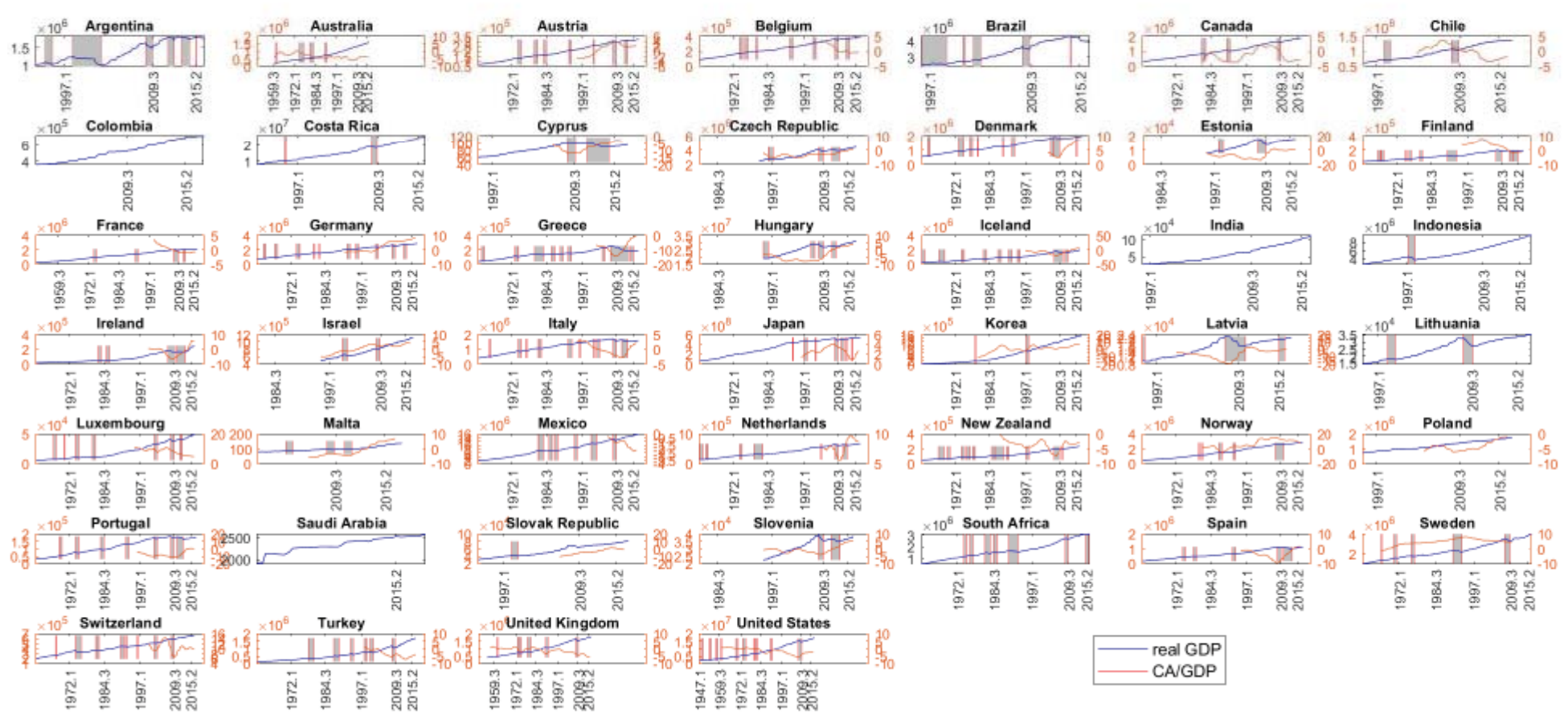


Figure 2: Chronology of business cycles (Bry-Boschan method) and NFA/GDP

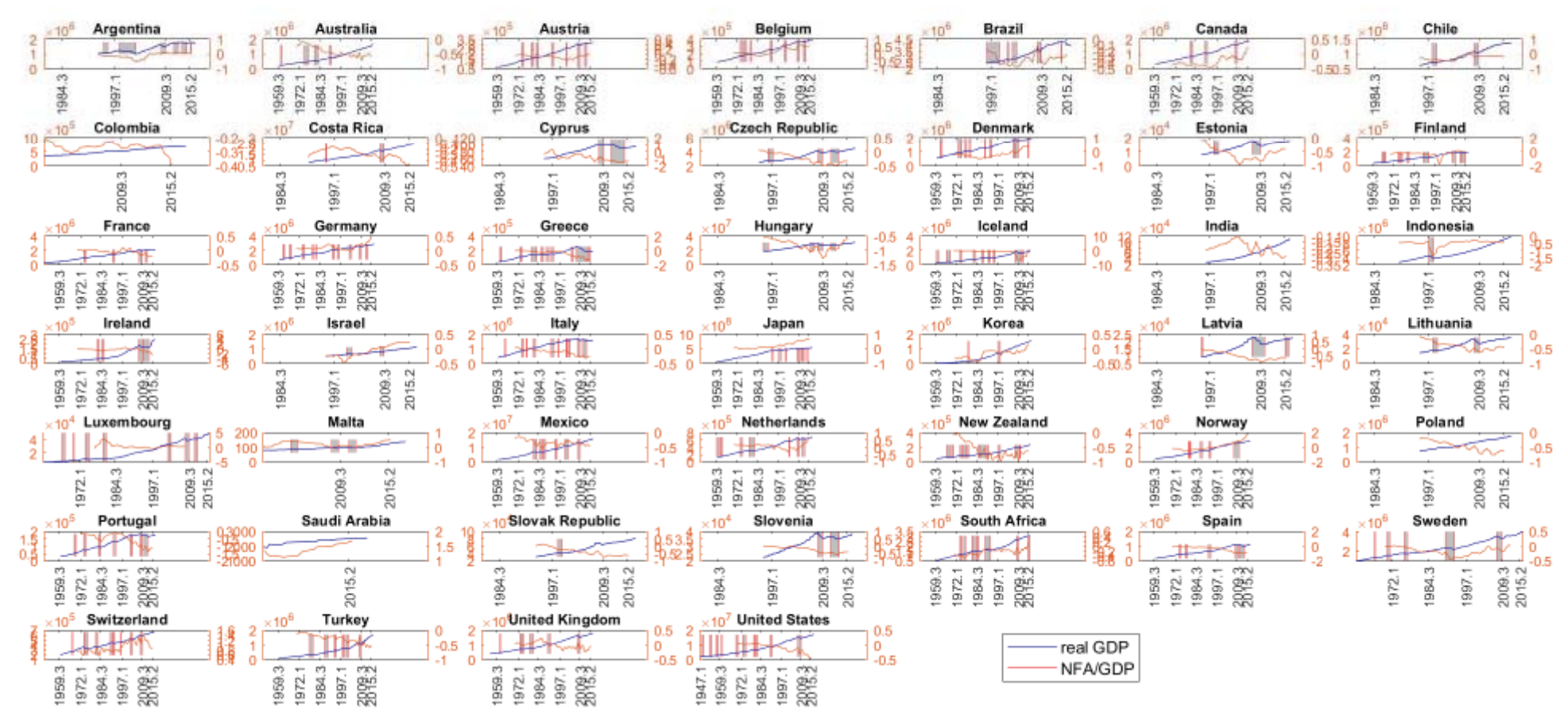


Figure 3: Traditional measures of expansions. Average values by country.
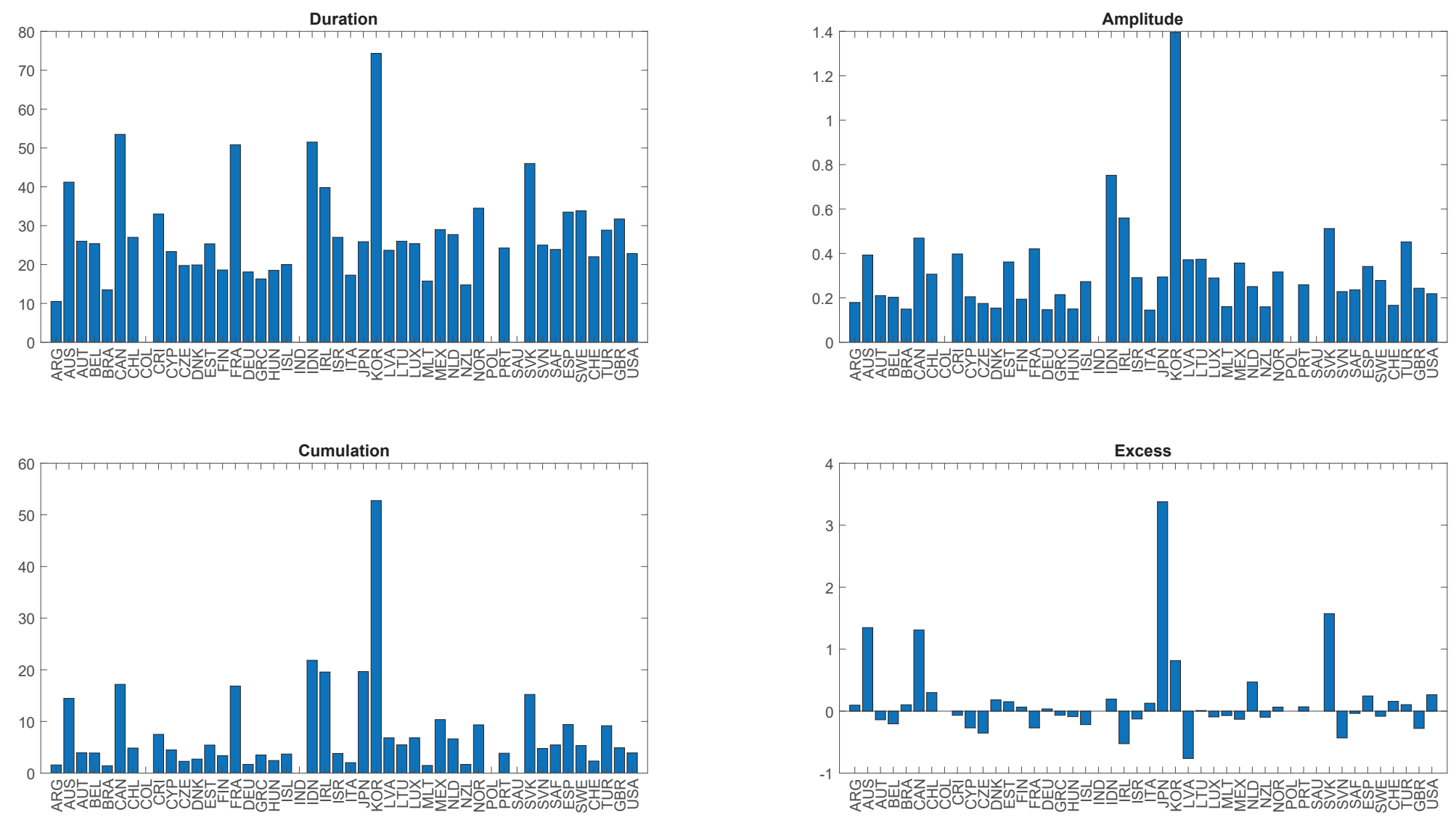
Figure 4: Shaped-related measures of expansions. Average values by country.

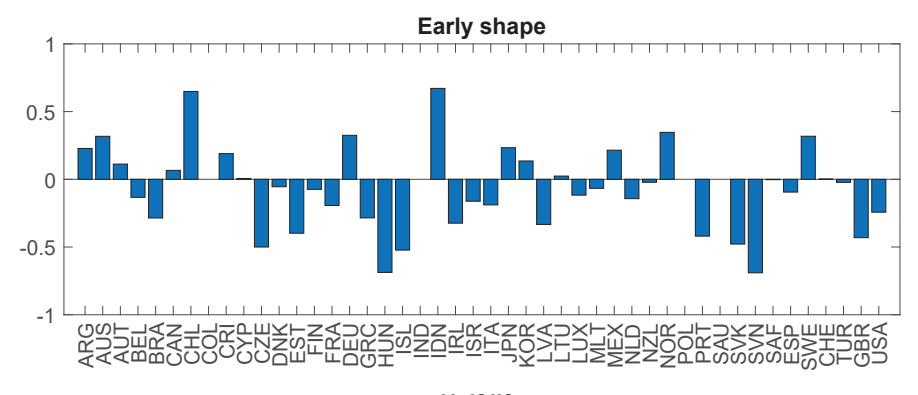

Half life
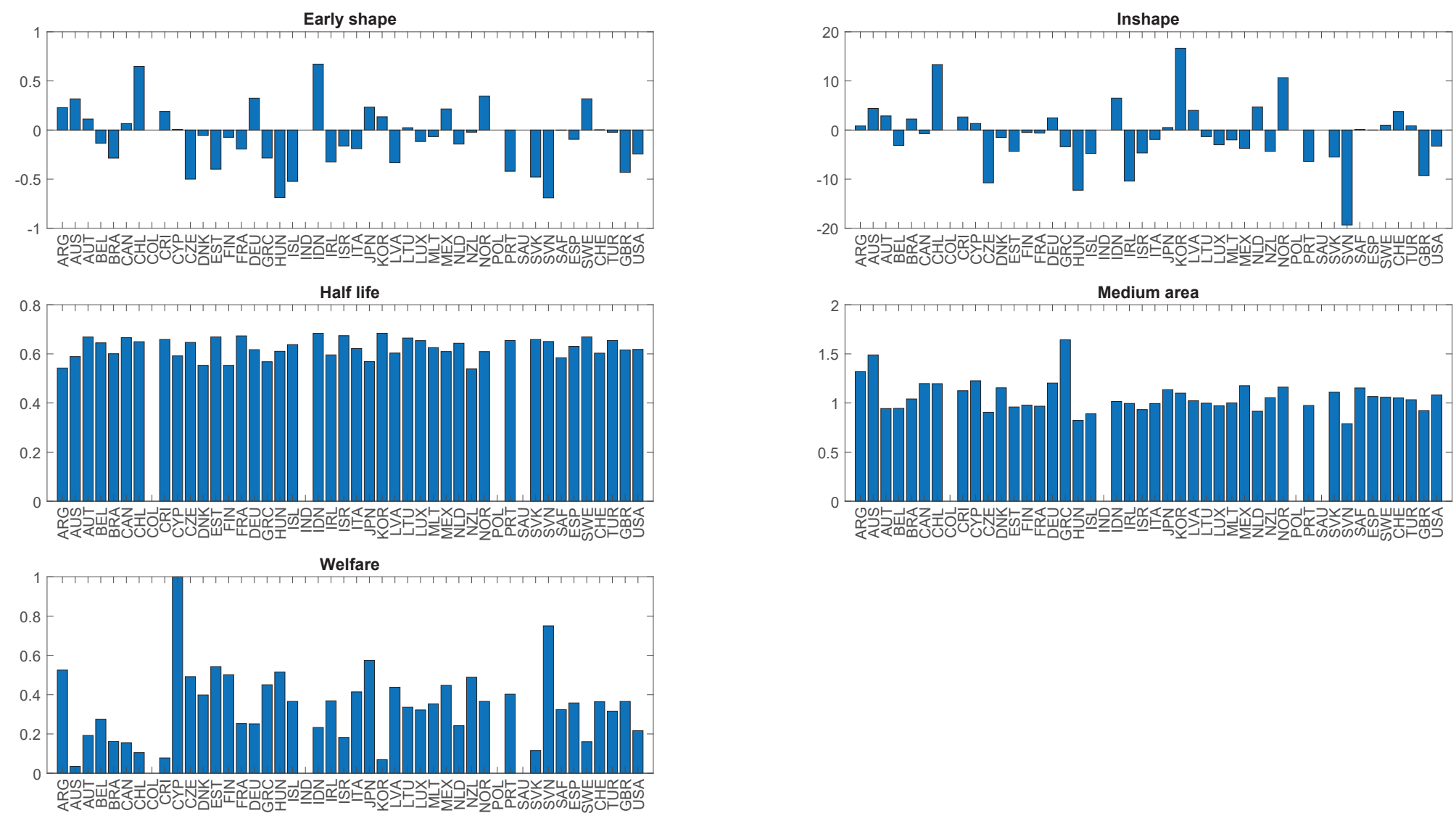
Figure 5: Geographical and income control variables
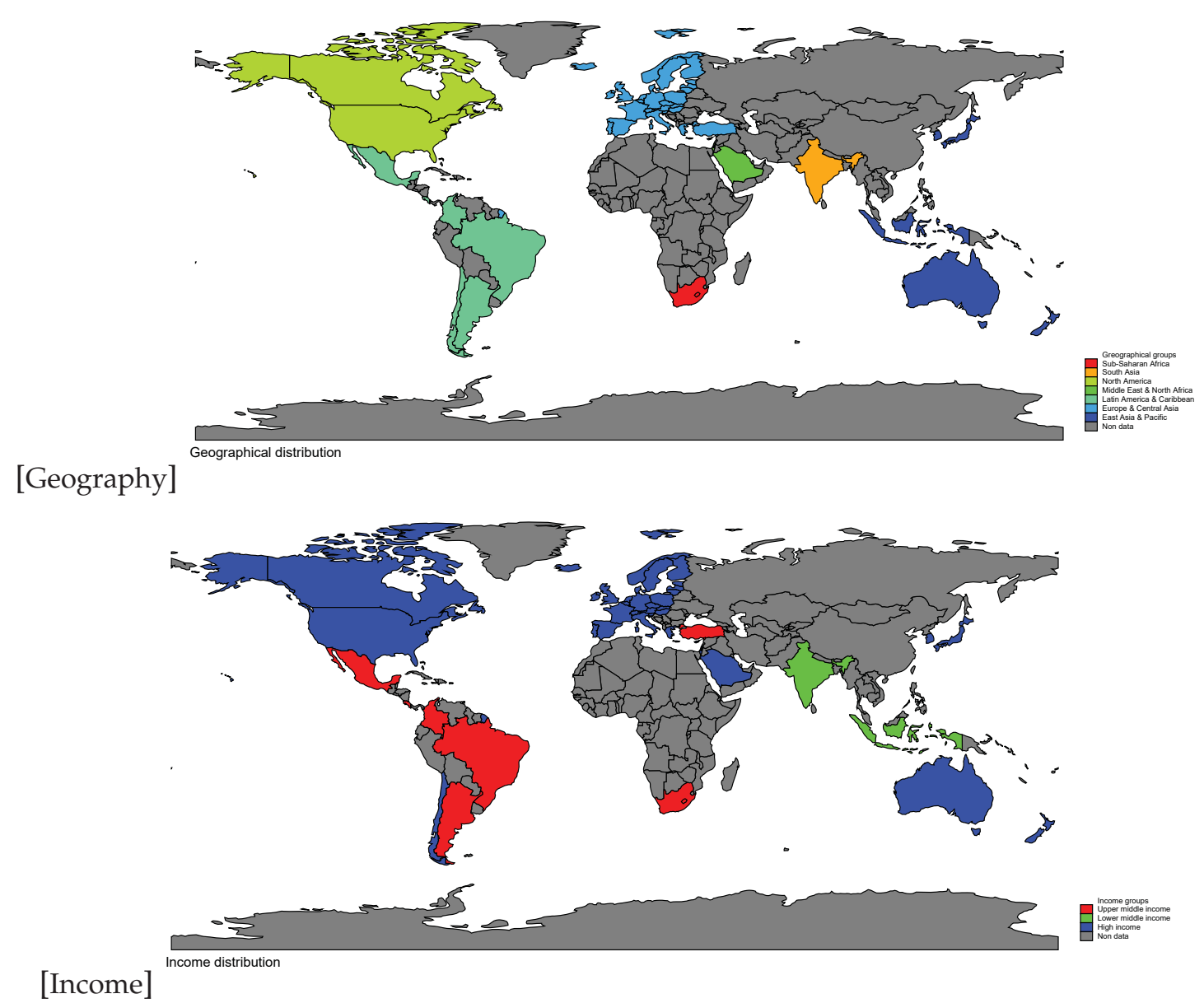


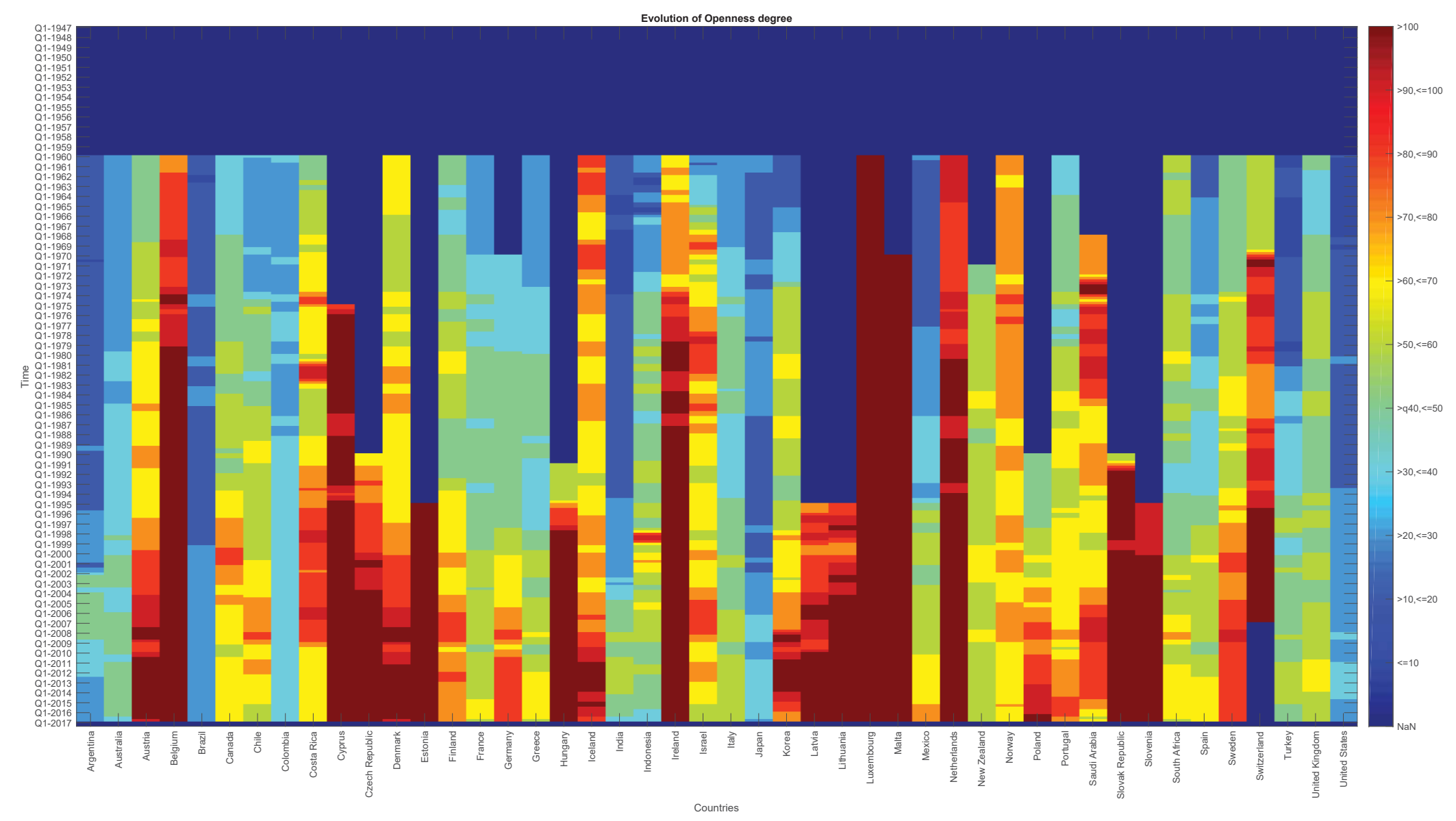


Figure 7: Evolution of Exchange rate regimes by country and period

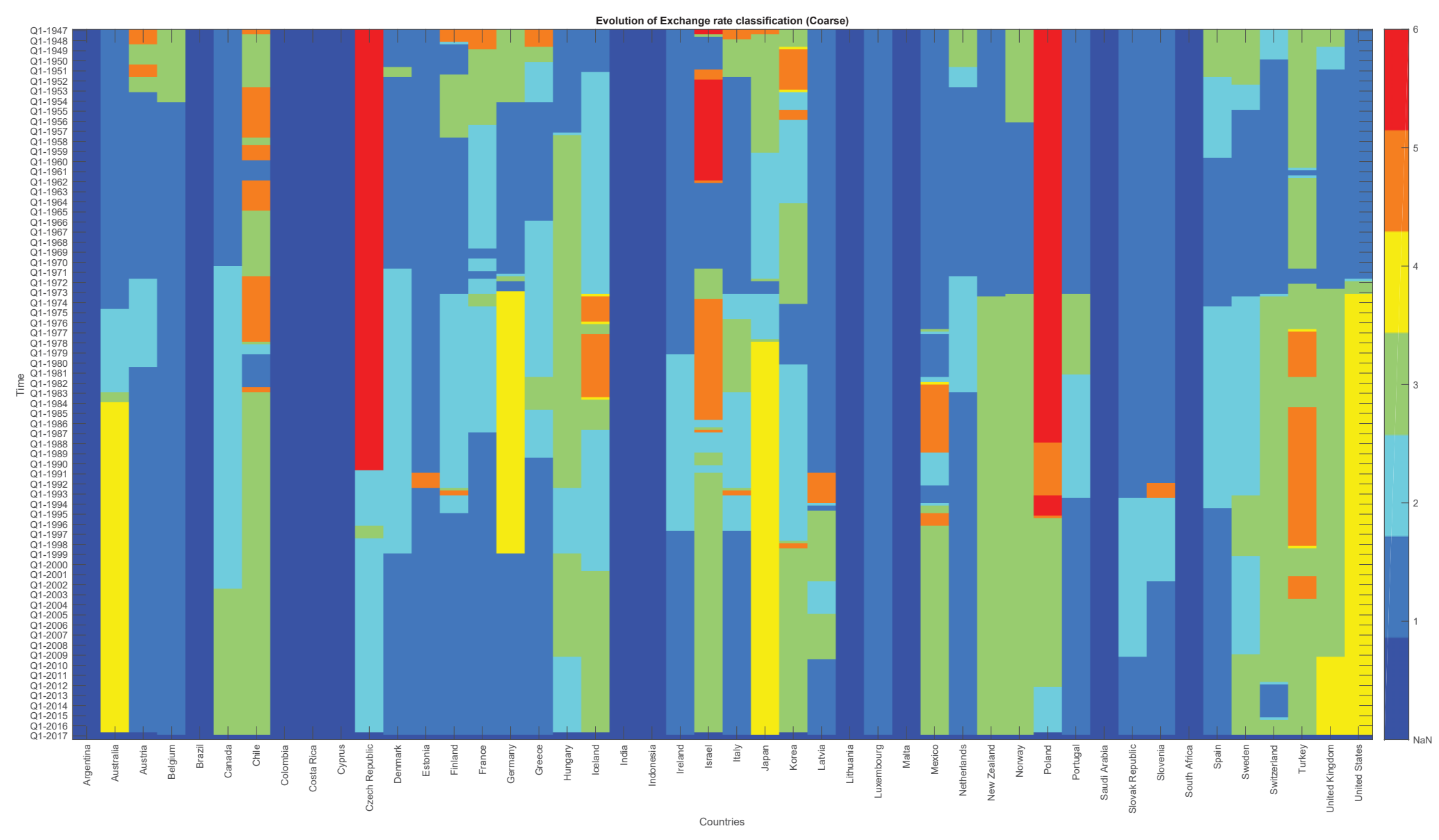




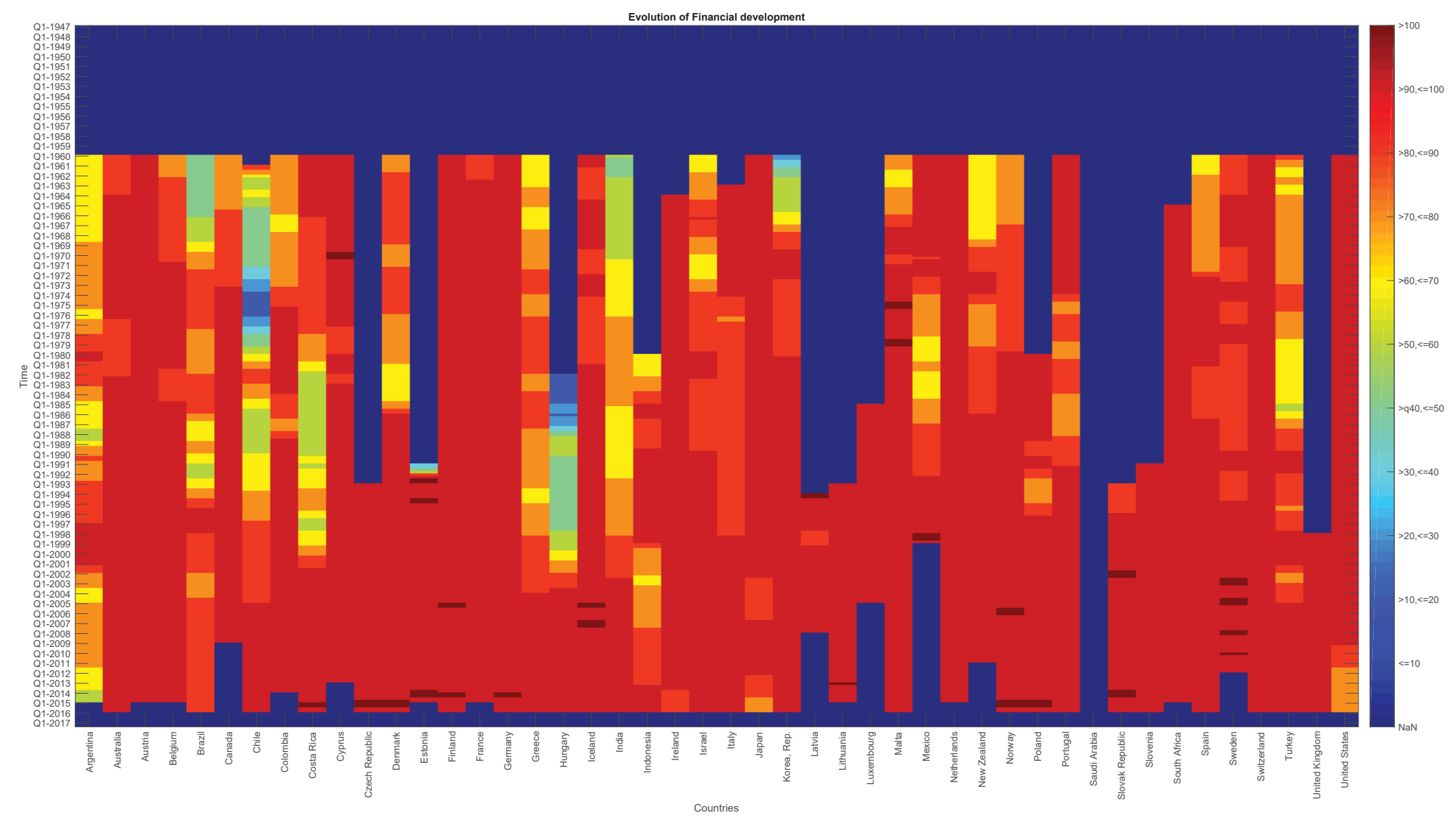


Figure 9: Evolution of Financial openness by country and period

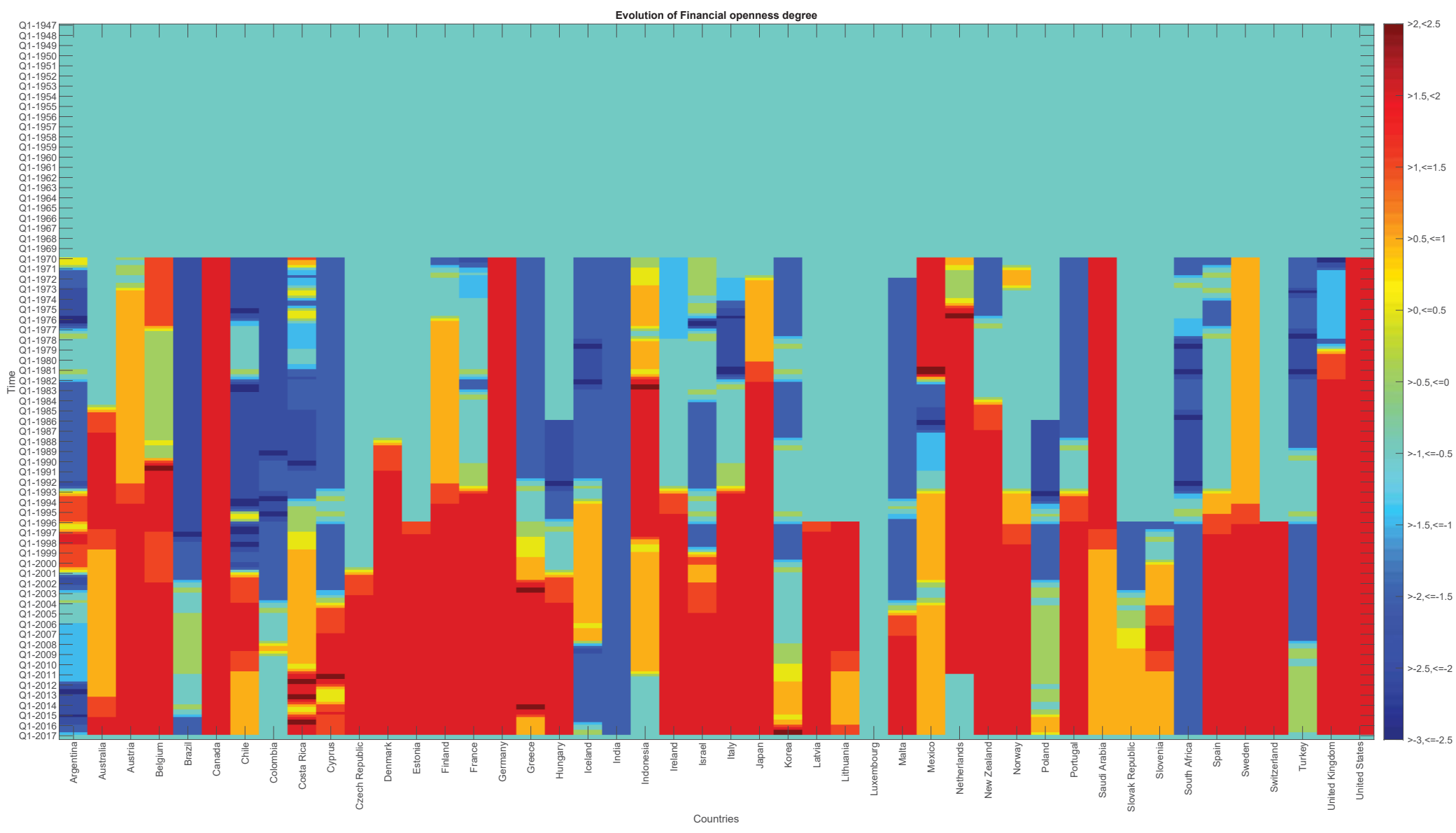


Figure 10: Evolution of oil prices

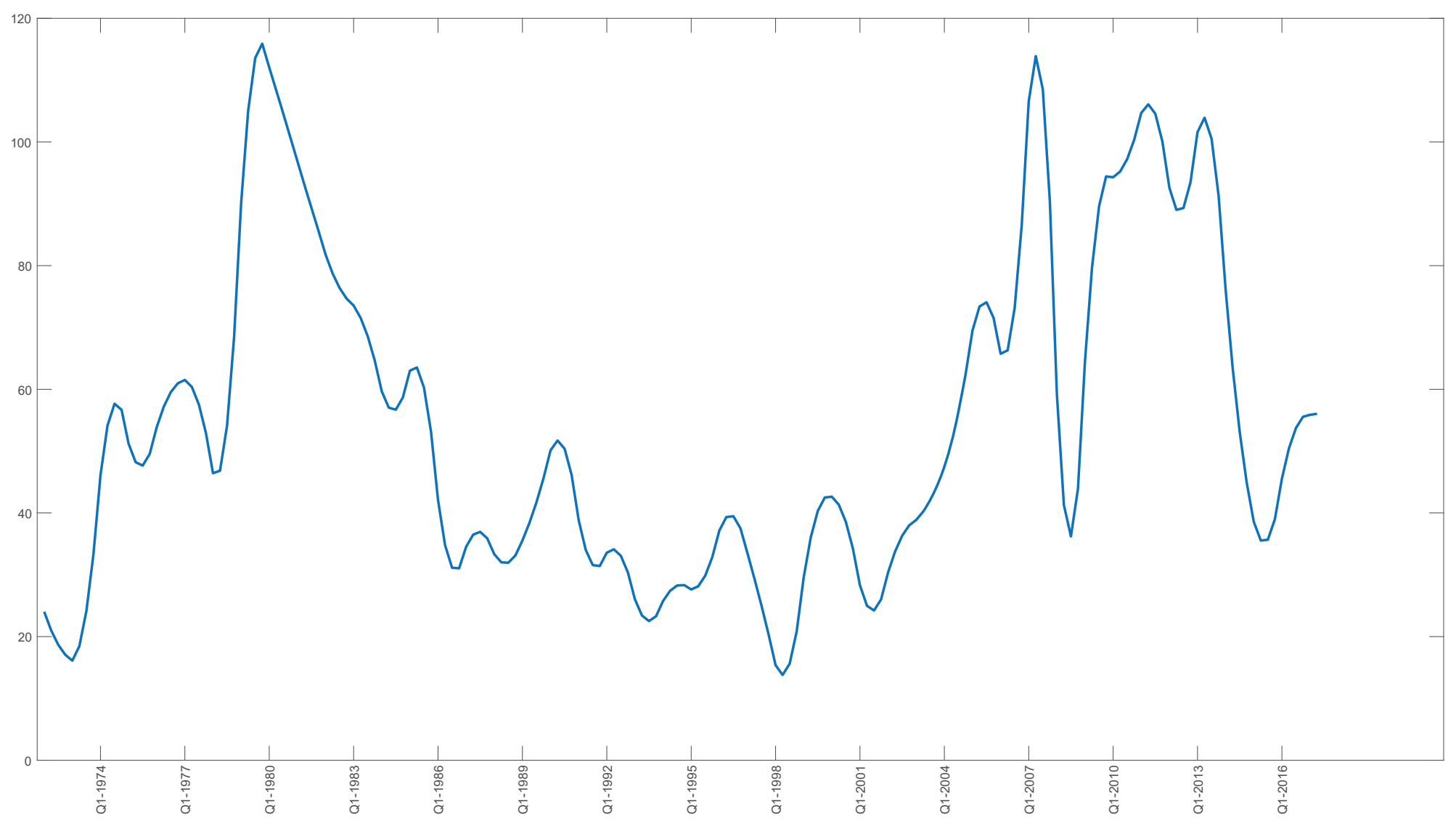


Figure 11: Evolution of Regulation of Labour Market by country and period

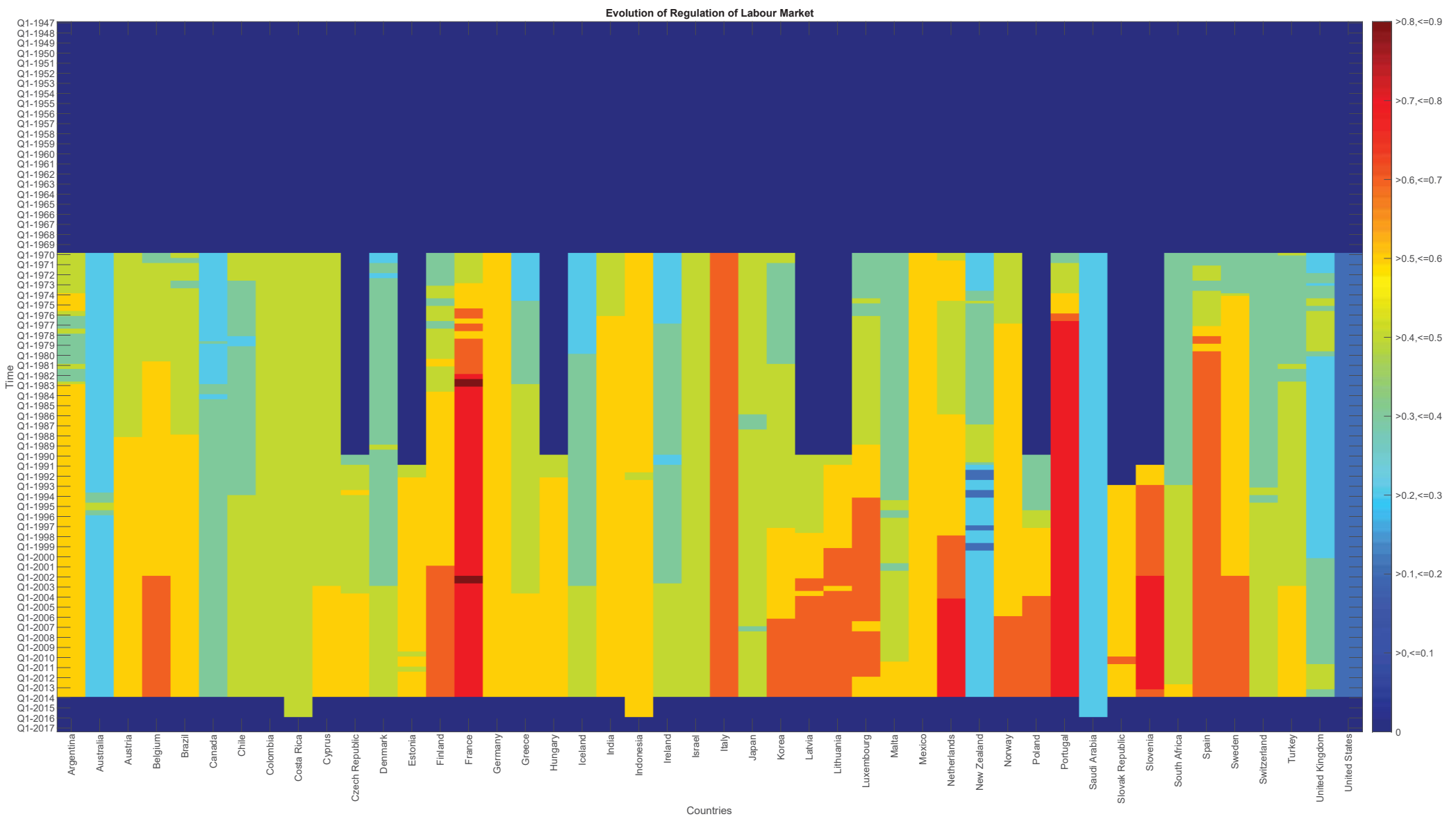


Figure 12: Typology of financial crises linked with expansions by countries

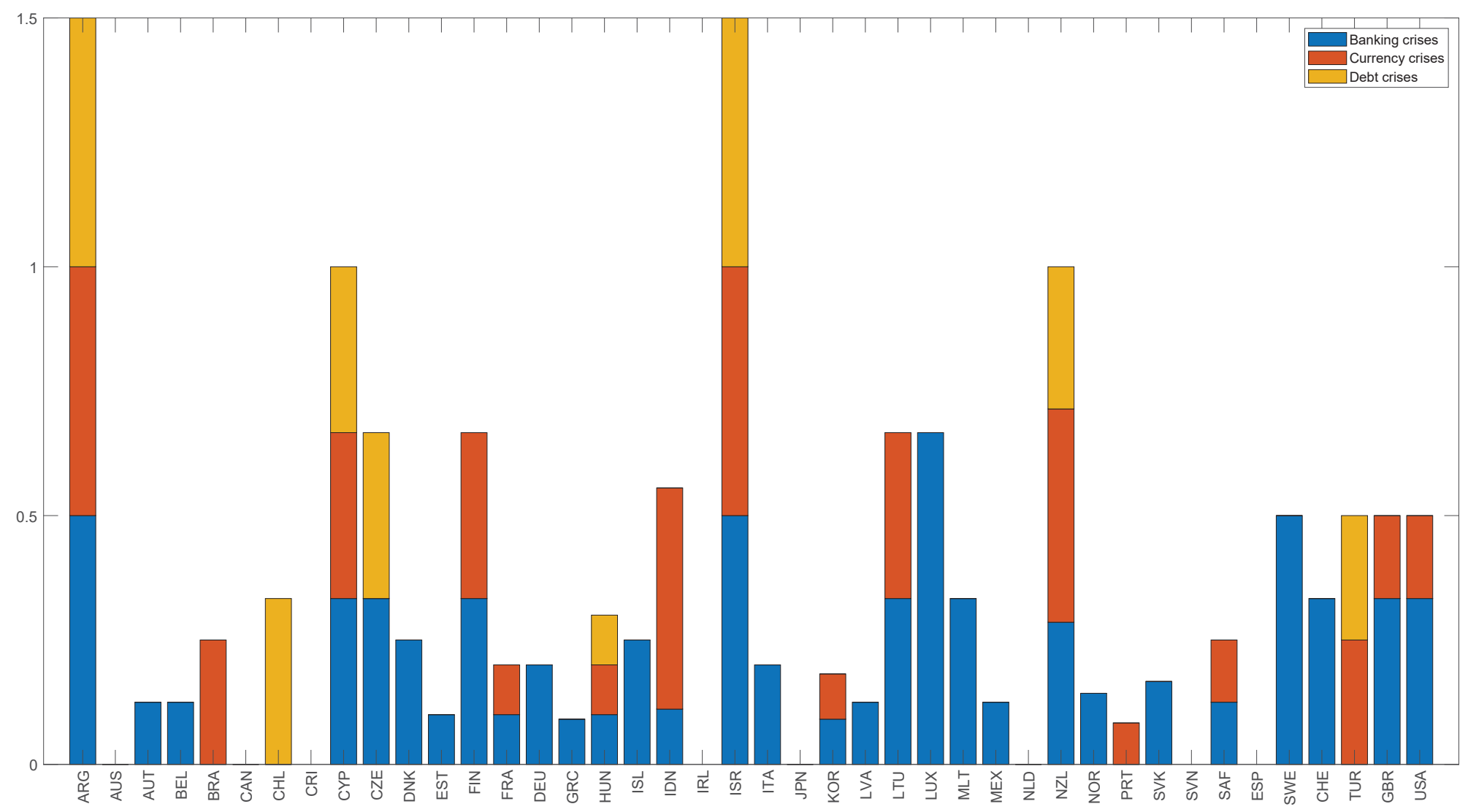




\section{Appendix 1}

Table A1: Descriptive statistics of variables

\begin{tabular}{|c|c|c|c|c|}
\hline Variables & Mean & Standard deviation & Skewness & Kurtosis \\
\hline \multicolumn{5}{|c|}{ ENDOGENOUS } \\
\hline Duration & 25.62 & 21.94 & 1.60 & 5.82 \\
\hline Amplitude & 0.27 & 0.30 & 2.46 & 10.96 \\
\hline Cumulation & 6.53 & 14.39 & 5.56 & 47.96 \\
\hline Excess & 0.16 & 1.91 & 10.87 & 152.81 \\
\hline Early shape & -0.07 & 0.76 & 0.18 & 1.66 \\
\hline Inshape & -1.14 & 15.57 & -0.21 & 9.64 \\
\hline Half life & 0.62 & 0.11 & -2.17 & 7.97 \\
\hline Medium area & 1.07 & 0.56 & 7.25 & 86.73 \\
\hline Time-to-recovery & 0.36 & 0.34 & 0.97 & 2.48 \\
\hline \multicolumn{5}{|c|}{ EXOGENOUS CA (group1) } \\
\hline CA1 & -0.92 & 4.71 & 0.23 & 3.57 \\
\hline CA2 & -1.06 & 4.94 & 0.16 & 3.54 \\
\hline CA3 & -1.09 & 5.15 & 0.10 & 3.69 \\
\hline CA4 & -1.09 & 5.24 & 0.07 & 3.76 \\
\hline CA5 & -0.47 & 4.64 & 0.11 & 3.98 \\
\hline CA6 & -0.78 & 4.72 & 0.25 & 3.24 \\
\hline CA7 & -0.19 & 0.88 & 0.37 & 1.40 \\
\hline CA8 & -0.47 & 1.01 & 0.09 & 3.17 \\
\hline CA9 & 0.34 & 0.48 & 0.66 & 1.44 \\
\hline CA10 & 0.30 & 0.46 & 0.89 & 1.79 \\
\hline \multicolumn{5}{|c|}{ EXOGENOUS CA (group2) } \\
\hline CA11 & -0.24 & 4.67 & 0.26 & 3.19 \\
\hline CA12 & -0.38 & 4.32 & 0.27 & 3.54 \\
\hline CA13 & -0.38 & 5.50 & -0.22 & 3.66 \\
\hline CA14 & 0.20 & 0.36 & 1.43 & 3.32 \\
\hline CA15 & 3.05 & 1.76 & 0.26 & 1.76 \\
\hline \multicolumn{5}{|c|}{ EXOGENOUS NFA (group1) } \\
\hline NFA1 & -0.24 & 0.70 & -4.91 & 42.91 \\
\hline NFA2 & -0.23 & 0.71 & -5.05 & 44.03 \\
\hline NFA3 & -0.22 & 0.68 & -4.75 & 40.53 \\
\hline NFA4 & -0.21 & 0.64 & -4.57 & 39.86 \\
\hline NFA5 & -0.26 & 0.75 & -3.62 & 26.45 \\
\hline NFA6 & -0.18 & 0.55 & -4.49 & 47.59 \\
\hline NFA7 & -0.43 & 0.84 & 0.95 & 2.09 \\
\hline NFA8 & -0.27 & 0.67 & -0.95 & 5.88 \\
\hline NFA9 & 0.31 & 0.46 & 0.82 & 1.67 \\
\hline NFA10 & 0.22 & 0.42 & 1.34 & 2.80 \\
\hline NFA11 & 0.94 & 0.77 & 0.81 & 3.78 \\
\hline \multicolumn{5}{|c|}{ EXOGENOUS NFA (group2) } \\
\hline NFA12 & -0.20 & 0.59 & -3.40 & 32.08 \\
\hline NFA13 & -0.23 & 0.63 & -3.74 & 30.49 \\
\hline NFA14 & -0.20 & 0.60 & -3.62 & 36.14 \\
\hline NFA15 & 2.79 & 1.74 & 0.50 & 1.99 \\
\hline \multicolumn{5}{|c|}{ CONTROL } \\
\hline Geography & 2.36 & 1.22 & 2.22 & 8.14 \\
\hline Income & 1.28 & 0.69 & 2.09 & 5.39 \\
\hline Trade openness & 71.77 & 51.32 & 2.32 & 10.25 \\
\hline Exchange rate regime & 2.08 & 1.20 & 0.82 & 2.66 \\
\hline Financial development & 91.26 & 10.90 & -2.12 & 9.00 \\
\hline Financial openness & 0.99 & 1.48 & -0.52 & 1.73 \\
\hline Oil prices & 57.23 & 22.28 & 0.35 & 2.11 \\
\hline Labour market regulation & 0.48 & 0.14 & -0.19 & 2.97 \\
\hline Banking crisis & 0.16 & 0.37 & 1.83 & 4.36 \\
\hline Currency crises & 0.11 & 0.31 & 2.52 & 7.37 \\
\hline Debt crisis & 0.05 & 0.22 & 4.12 & 17.98 \\
\hline
\end{tabular}




\section{BANCO DE ESPAÑA PUBLICATIONS}

\section{WORKING PAPERS}

1910 JAMES COSTAIN, ANTON NAKOV and BORJA PETIT: Monetary policy implications of state-dependent prices and wages

1911 JAMES CLOYNE, CLODOMIRO FERREIRA, MAREN FROEMEL and PAOLO SURICO: Monetary policy, corporate finance and investment.

1912 CHRISTIAN CASTRO and JORGE E. GALÁN: Drivers of productivity in the Spanish banking sector: recent evidence.

1913 SUSANA PÁRRAGA RODRÍGUEZ: The effects of pension-related policies on household spending.

1914 MÁXIMO CAMACHO, MARÍA DOLORES GADEA and ANA GÓMEZ LOSCOS: A new approach to dating the reference cycle.

1915 LAURA HOSPIDO, LUC LAEVEN and ANA LAMO: The gender promotion gap: evidence from Central Banking.

1916 PABLO AGUILAR, STEPHAN FAHR, EDDIE GERBA and SAMUEL HURTADO: Quest for robust optimal macroprudential policy.

1917 CARMEN BROTO and MATÍAS LAMAS: Is market liquidity less resilient after the financial crisis? Evidence for US treasuries.

1918 LAURA HOSPIDO and CARLOS SANZ: Gender Gaps in the Evaluation of Research: Evidence from Submissions to Economics Conferences.

1919 SAKI BIGIO, GALO NUÑO and JUAN PASSADORE: A framework for debt-maturity management.

1920 LUIS J. ÁLVAREZ, MARÍA DOLORES GADEA and ANA GÓMEZ-LOSCOS: Inflation interdependence in advanced economies.

1921 DIEGO BODAS, JUAN R. GARCÍA LÓPEZ, JUAN MURILLO ARIAS, MATÍAS J. PACCE, TOMASA RODRIGO LÓPEZ, JUAN DE DIOS ROMERO PALOP, PEP RUIZ DE AGUIRRE, CAMILO A. ULLOA and HERIBERT VALERO LAPAZ: Measuring retail trade using card transactional data.

1922 MARIO ALLOZA and CARLOS SANZ: Jobs multipliers: evidence from a large fiscal stimulus in Spain.

1923 KATARZYNA BUDNIK, MASSIMILIANO AFFINITO, GAIA BARBIC, SAIFFEDINE BEN HADJ, ÉDOUARD CHRÉTIEN, HANS DEWACHTER, CLARA ISABEL GONZÁLEZ, JENNY HU, LAURI JANTUNEN, RAMONA JIMBOREAN, OTSO MANNINEN, RICARDO MARTINHO, JAVIER MENCÍA, ELENA MOUSARRI, LAURYNAS NARUŠEVIČIUS, GIULIO NICOLETTI, MICHAEL O'GRADY, SELCUK OZSAHIN, ANA REGINA PEREIRA, JAIRO RIVERA-ROZO, CONSTANTINOS TRIKOUPIS, FABRIZIO VENDITTI and SOFÍA VELASCO: The benefits and costs of adjusting bank capitalisation: evidence from Euro Area countries.

1924 MIGUEL ALMUNIA and DAVID LÓPEZ-RODRÍGUEZ: The elasticity of taxable income in Spain: 1999-2014.

1925 DANILO LEIVA-LEON and LORENZO DUCTOR: Fluctuations in global macro volatility.

1926 JEF BOECKX, MAARTEN DOSSCHE, ALESSANDRO GALESI, BORIS HOFMANN and GERT PEERSMAN: Do SVARs with sign restrictions not identify unconventional monetary policy shocks?

1927 DANIEL DEJUÁN and JUAN S. MORA-SANGUINETTI: Quality of enforcement and investment decisions. Firm-level evidence from Spain.

1928 MARIO IZQUIERDO, ENRIQUE MORAL-BENITO and ELVIRA PRADES: Propagation of sector-specific shocks within Spain and other countries.

1929 MIGUEL CASARES, LUCA DEIDDA and JOSÉ E. GALDÓN-SÁNCHEZ: On financial frictions and firm market power.

1930 MICHAEL FUNKE, DANILO LEIVA-LEON and ANDREW TSANG: Mapping China's time-varying house price landscape.

1931 JORGE E. GALÁN and MATÍAS LAMAS: Beyond the LTV ratio: new macroprudential lessons from Spain.

1932 JACOPO TIMINI: Staying dry on Spanish wine: the rejection of the 1905 Spanish-Italian trade agreement.

1933 TERESA SASTRE and LAURA HERAS RECUERO: Domestic and foreign investment in advanced economies. The role of industry integration.

1934 DANILO LEIVA-LEON, JAIME MARTÍNEZ-MARTÍN and EVA ORTEGA: Exchange rate shocks and inflation comovement in the euro area.

1935 FEDERICO TAGLIATI: Child labor under cash and in-kind transfers: evidence from rural Mexico.

1936 ALBERTO FUERTES: External adjustment with a common currency: the case of the euro area.

1937 LAURA HERAS RECUERO and ROBERTO PASCUAL GONZÁLEZ: Economic growth, institutional quality and financial development in middle-income countries.

1938 SILVIA ALBRIZIO, SANGYUP CHOI, DAVIDE FURCERI and CHANSIK YOON: International Bank Lending Channel of Monetary Policy.

1939 MAR DELGADO-TÉLLEZ, ENRIQUE MORAL-BENITO and JAVIER J. PÉREZ: Outsourcing and public expenditure: an aggregate perspective with regional data. 
1940 MYROSLAV PIDKUYKO: Heterogeneous spillovers of housing credit policy.

1941 LAURA ÁLVAREZ ROMÁN and MIGUEL GARCÍA-POSADA GÓMEZ: Modelling regional housing prices in Spain.

1942 STÉPHANE DÉES and ALESSANDRO GALESI: The Global Financial Cycle and US monetary policy in an interconnected world.

1943 ANDRÉS EROSA and BEATRIZ GONZÁLEZ: Taxation and the life cycle of firms.

1944 MARIO ALLOZA, JESÚS GONZALO and CARLOS SANZ: Dynamic effects of persistent shocks.

1945 PABLO DE ANDRÉS, RICARDO GIMENO and RUTH MATEOS DE CABO: The gender gap in bank credit access.

1946 IRMA ALONSO and LUIS MOLINA: The SHERLOC: an EWS-based index of vulnerability for emerging economies.

1947 GERGELY GANICS, BARBARA ROSSI and TATEVIK SEKHPOSYAN: From Fixed-event to Fixed-horizon Density Forecasts: Obtaining Measures of Multi-horizon Uncertainty from Survey Density Forecasts.

1948 GERGELY GANICS and FLORENS ODENDAHL: Bayesian VAR Forecasts, Survey Information and Structural Change in the Euro Area.

2001 JAVIER ANDRÉS, PABLO BURRIEL and WENYI SHEN: Debt sustainability and fiscal space in a heterogeneous Monetary Union: normal times vs the zero lower bound.

2002 JUAN S. MORA-SANGUINETTI and RICARDO PÉREZ-VALLS: ¿Cómo afecta la complejidad de la regulación a la demografía empresarial? Evidencia para España.

2003 ALEJANDRO BUESA, FRANCISCO JAVIER POBLACIÓN GARCÍA and JAVIER TARANCÓN: Measuring the procyclicality of impairment accounting regimes: a comparison between IFRS 9 and US GAAP.

2004 HENRIQUE S. BASSO and JUAN F. JIMENO: From secular stagnation to robocalypse? Implications of demographic and technological changes.

2005 LEONARDO GAMBACORTA, SERGIO MAYORDOMO and JOSÉ MARÍA SERENA: Dollar borrowing, firm-characteristics, and FX-hedged funding opportunities.

2006 IRMA ALONSO ÁLVAREZ, VIRGINIA DI NINO and FABRIZIO VENDITTI: Strategic interactions and price dynamics in the global oil market.

2007 JORGE E. GALÁN: The benefits are at the tail: uncovering the impact of macroprudential policy on growth-at-risk.

2008 SVEN BLANK, MATHIAS HOFFMANN and MORITZ A. ROTH: Foreign direct investment and the equity home bias puzzle.

2009 AYMAN EL DAHRAWY SÁNCHEZ-ALBORNOZ and JACOPO TIMINI: Trade agreements and Latin American trade (creation and diversion) and welfare.

2010 ALFREDO GARCÍA-HIERNAUX, MARÍA T. GONZÁLEZ-PÉREZ and DAVID E. GUERRERO: Eurozone prices: a tale of convergence and divergence.

2011 ÁNGEL IVÁN MORENO BERNAL and CARLOS GONZÁLEZ PEDRAZ: Análisis de sentimiento del Informe de Estabilidad Financiera.

2012 MARIAM CAMARERO, MARÍA DOLORES GADEA-RIVAS, ANA GÓMEZ-LOSCOS and CECILIO TAMARIT: External imbalances and recoveries.

\section{BANCODEESPAÑA}

Eurosistema
Unidad de Servicios Generales

Alcalá, 48 - 28014 Madrid

E-mail: publicaciones@bde.es www.bde.es 